\title{
Correlation of NQR and Chemical Bond Parameters*
}

\author{
Alarich Weiss and Silvia Wigand \\ Institut für Physikalische Chemie, Physikalische Chemie III, Technische Hochschule Darmstadt, \\ Darmstadt, West Germany
}

Z. Naturforsch. 45 a, 195-212 (1990); received August 9, 1989

\begin{abstract}
Nuclear quadrupole resonance is an effective spectroscopic method to investigate the charge density distribution in solids. The range of compounds which may be investigated is wide, reaching from a crystal lattice built up by an ordered arrangement of neutral molecules in the crystalline material to ionic crystals and to metallic solids.

First the correlations between NQR quantities and bond parameters which become apparent from the molecular orbital picture will be discussed, e.g. Hammett $\sigma, \chi$-parameter, ionic character $i$, $s$-character, ionicity, electronegativity in their connection to NQR. Then, the correlations of NQR frequencies, respectively nuclear quadrupole coupling constants, with bond lengths and bond angles are considered.

Cross correlations, e.g. of NQR frequencies with bond distances, bond distances with vibrational frequencies, and vibrational frequencies with NQR frequencies are discussed as are $p K_{\mathrm{A}}$ dependencies of NQR parameters. The connection of $e \Phi_{z z} Q h^{-1}\left({ }^{14} \mathrm{~N}\right)$ in pharmaceuticals with their biological activity is pointed out.
\end{abstract}

\section{Introduction}

There are many approaches to chemistry, the branch of science which synthesizes and analyses molecules, the chemical items. Chemists are faced with a multibranched (multidimensional) countable infinite set of items, and each day the set grows by thousands of them. The problem of the science "Chemistry" is, to understand the relations, the elective affinities between the items which govern their phenomenology. The ideal object of the theory of chemistry is, to find the unified theory, the unified model of chemistry. Presently it is, however, impossible to reach such a goal; but to try paths towards it is our task. At the time being, it ends up in a numerical solution of the Hamiltonian, for each item a separate set of information, based on results decoupled from functional interdependences. The recognition of elective affinities, extrapolating and interpolating "neighboring" items, this is very difficult on such a basis. The other extremum is the purely empirical way of collecting data and compiling them in huge data banks which contain all the information for anybody who primarily whishes to be informed but not to know about the backbone.

\footnotetext{
* Presented at the Xth International Symposium on Nuclear Quadrupole Resonance Spectroscopy, Takayama, Japan, August 22-26, 1989.

Reprint requests to Prof. Dr. Al. Weiss, Institut für Physikalische Chemie III, Technische Hochschule Darmstadt, Petersenstraße 20, D-6100 Darmstadt.
}

We think that a way in between is the only one to get a system in the countable set of chemical items. It is the experiment to recognize patterns in the sea of information and to try to rationalize such patterns according to laws based on first principles. Such a way was followed up in chemistry since a long time. It is the way to correlate elective affinities and items within a functional dependence.

The discovery of the experimental access to hyperfine interactions between the nuclear electric quadrupole moment $e Q$ and an electric field gradient tensor $\widetilde{\Phi}_{i i}, i=x, y, z$, in solids by Dehmelt and Krüger [1-3] and by Pound [4] in 1950 was immediately transferred as a spectroscopic method to applications in the field of Chemistry. Both experimental approaches, [1] and [4], are today of equal importance in solid state chemistry, and the solid state is a necessary experimental condition but by no means the crucial question. Pure nuclear quadrupole resonance, NQR, [1] and nuclear quadrupole interactions, studied in nuclear magnetic resonance as a fine structure of the NMR spectrum [4] are solely different in the experimental approach. Large nuclear quadrupole interaction energies lead to energy level separations of several $\mathrm{MHz}$ and up. Then NQR is the preferable choice of experiment. In the case of small nuclear quadrupole interaction energies - level splittings of $<1 \mathrm{MHz}-$ a drastic change in the Boltzmann distribution of level population by application of strong magnetic fields $\boldsymbol{B}_{0}$ to nuclear magnetic moments $\boldsymbol{\mu}$ in the solid and thereby a creation of the situation $\mu B_{0} \gg e \Phi_{z z} Q h^{-1}$ [4] is superior to

0932-0784 / $90 / 0300-0195 \$ 01.30 / 0$. - Please order a reprint rather than making your own copy. 
NQR. In the product describing the nuclear quadrupole coupling constant (NQCC), $e \Phi_{z z} Q h^{-1}, e$ is the unit charge, $Q$ the nuclear electric quadrupole moment, $h$ the Planck constant, and $\Phi_{z z}$ the main principal axis of the electric field gradient tensor (EFGT) $\tilde{\Phi}_{i i}$, $i=x, y, z$. The continuous progress in the development of high field superconducting magnets should push the study of weak nuclear quadrupole interactions in future.

The reason for applying NQR and the study of the quadrupole induced fine structure of NMR, QFSNMR, as a spectroscopic method to chemistry is obvious. The energy level scheme and therefrom the observable energy differences are connected in a very simple way with the basic observables of quantum chemistry, the electron distribution $\varrho(x, y, z) \mathrm{d} \tau$.

$$
e \Phi_{z z} Q h^{-1} \propto \int_{0}^{\infty} \varrho(x, y, z) \mathrm{d} \tau / r^{3} .
$$

The knowledge of $\varrho(x, y, z) \mathrm{d} \tau$ is the key to the understanding of chemical bond, and no other spectroscopic method besides microwave spectroscopy gives such a direct access to it than NQR. The determination of the electric field gradient tensor is the result of both methods. Therefrom the charge distribution will be derived, and vice versa, see (1).

Here, we are not concerned with microwave spectroscopy, which is restricted to the gaseous phase and to rather simple chemical items out of the infinite set.

Speaking about NQR, we restrict ourselfes to the solid state. The information on nuclear quadrupole interactions one gaines from matter in the liquid state or in the partially ordered liquid state (liquid crystals) we shall not discuss, besides their interesting potentialities for evaluating the acting electric field gradient tensors, EFGT's.

In the following, we shall consider first NQR as a spectroscopic method in the chemistry of molecules which are, for experimental convenience, condensed into the solid state. Then, the intermolecular forces in the solid state can be regarded as weak perturbations of the chemical bond in the individual molecules. Such an approximation is, from the viewpoint of thermodynamics, an allowed one. The molar enthalpies of sublimation (the lattice energy) $\Delta \bar{H}_{\mathrm{s}}$ of crystals composed of uncharged, diamagnetic molecules are a few percent of the molar enthalpies $\Delta \bar{H}_{\mathrm{f}}$ of molecule formation.

In a second step, we shall consider the answers NQR and QFS-NMR offer for solids built up from charged molecules and atoms (ions). Weak nuclear quadrupole interaction energies are observed and, in the limit of ionic crystals, $e \Phi_{z z} Q h^{-1}$ is solely determined by interionic fields. There is, of course, a continuous transition from one extreme situation to the other. Several orders of magnitude in the electric field gradient, EFG, main principal axis $\Phi_{z z}$ may be acting on a nucleus. For example we consider the iodine atom: $e \Phi_{z z} Q h^{-1}\left({ }^{127} \mathrm{I}\right)$ is in the order of a few $\mathrm{MHz}$ in $\mathrm{AgI}$ and of two $\mathrm{GHz}$ in solid iodine.

The literature on NQR and QFS-NMR is numerous. Extensive treatments of experimental and theoretical aspects of NQR are given by Das and Hahn [5] and by Lucken [6]. QFS-NMR is thouroughly discussed by Cohen and Reif [7]. Compilations of NQR data have been published by Semin, Babushkina, and Yakobson [8] and by Chihara and Nakamura [9].

\section{Correlations of NQR and Intramolecular Bond Parameters}

Before the work of Dehmelt and Krüger [1 -3] and Pound [4], there was already a theoretical guide available to correlate NQR frequencies and nuclear quadrupole coupling constants, NQCC, to models of the chemical bond. This guide was given by Townes and Dailey in their pioneer work $[10,11]$. Relaying on a Molecular Orbital "Ansatz" they developed a simple relation between the nuclear quadrupole coupling constant $e \Phi_{z z} Q h^{-1}$, the $s$-character $s$ of a single bond the atom in question is forming with its partner, the ionic character $i$ of this bond, and the double bond character $\pi$ of the bond. An extensive discussion of the Townes-Dailey theory $[10,11]$ is given in $[5,6,8]$. In the case of carbon-halogen bonds $(\mathrm{C}-\mathrm{Cl}, \mathrm{C}-\mathrm{Br})$ one finds [12]

$$
\begin{aligned}
& \left(e \Phi_{z z} Q h^{-1}\right)_{\exp } /\left(e \Phi_{z z} Q h^{-1}\right)_{\mathrm{at}} \\
& \quad=(1-i-\pi)(1-s)+\frac{1}{2} \pi(1+c) .
\end{aligned}
$$

The double bond character can be found from [13]:

$\eta=(3 / 2) \pi(1+c)\left(e \Phi_{z z} Q h^{-1}\right)_{\mathrm{at}} /\left(e \Phi_{z z} Q h^{-1}\right)_{\mathrm{exp}}$.

$\eta$ is the asymmetry parameter of the EFG tensor, available from single crystal Zeeman split NQR experiments in $\mathrm{Cl}$ and $\mathrm{Br}$ NQR spectroscopy,

$$
\eta=\left|\Phi_{x x}-\Phi_{y y}\right| /\left|\Phi_{z z}\right| \text {. }
$$

For $\mathrm{Cl}\left(e \Phi_{z z} Q h^{-1}\right)_{\text {at }}$ is $109.6 \mathrm{MHz}$ and for bonds $\mathrm{C}-\mathrm{Cl}$ the correction factor $c$ is 0.15 . Therefrom one 


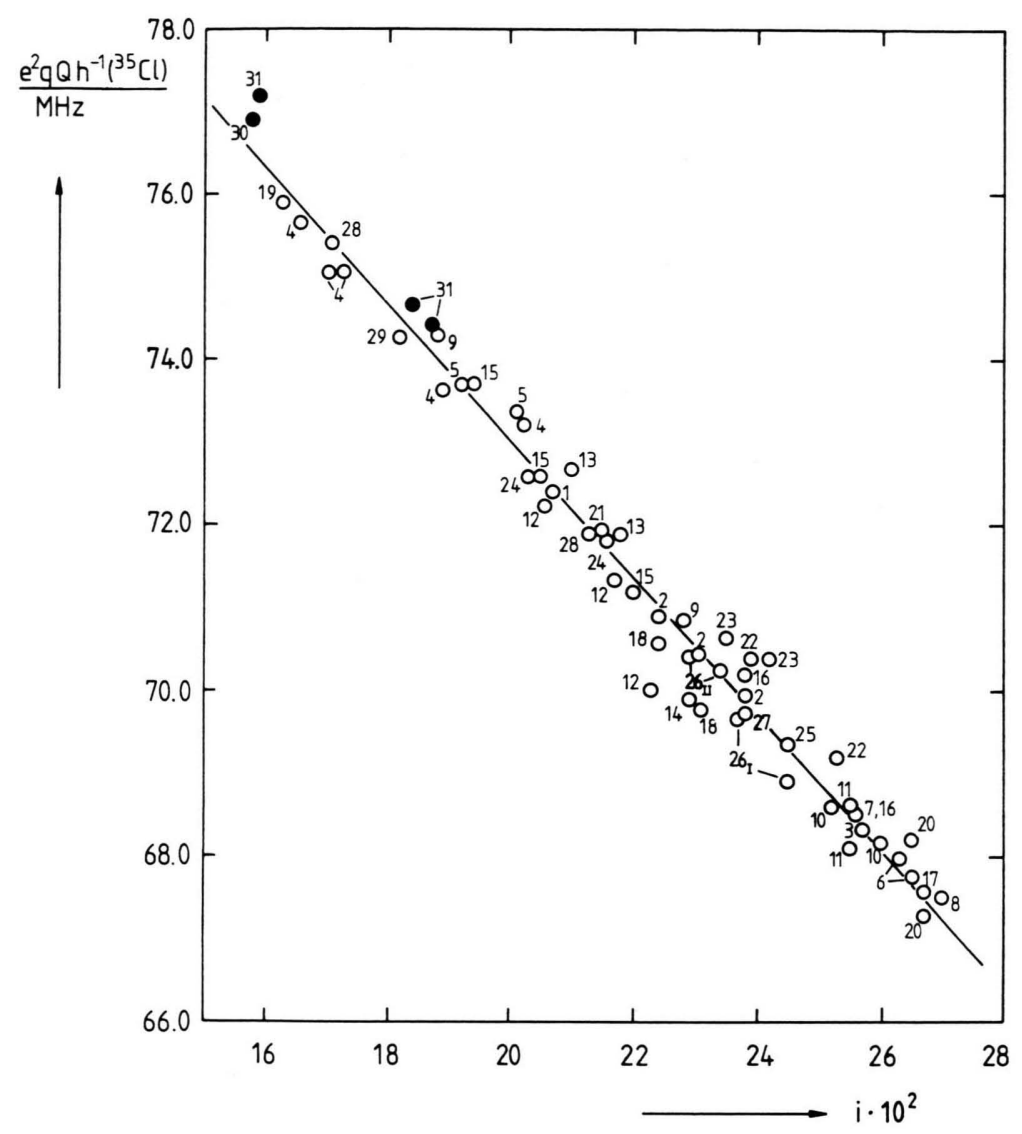

Fig. 1. Correlation between the nuclear quadrupole coupling constant of ${ }^{35} \mathrm{Cl}$ and the ionic character of the $\mathrm{C}-\mathrm{Cl}$ bond in chlorobenzenes. The numbering corresponds to that in Table 1 . The correlation is given by $\left(\Phi_{z z} \equiv e q\right)$

$$
\begin{array}{r}
e \Phi_{z z} Q h^{-1}\left({ }^{35} \mathrm{Cl}\right) / \mathrm{MHz} \\
=89.559-82.5 i .
\end{array}
$$

finds

$$
\pi=\left[\left(e \Phi_{z z} Q h^{-1}\right)_{\exp } / \mathrm{MHz}\right] \cdot \eta / 189.06
$$

and with (3)

$$
i=1-0.324 \pi-\left[\left(e \Phi_{z z} Q h^{-1}\right)_{\exp } / \mathrm{MHz}\right] / 93.16 .
$$

An example for the correlation between the ionic character $i$ and the NQCC of ${ }^{35} \mathrm{Cl}$ in benzene derivatives we show in Fig. 1. For 31 compounds, $e \Phi_{z z} Q h^{-1}\left({ }^{35} \mathrm{Cl}\right)$ is plotted as a function of $i$; the relation is derived from the ${ }^{35} \mathrm{Cl}-\mathrm{NQR}$ Zeeman experiment via (5) and (6). The numbers in Fig. 1 correspond to the numbers in Table 1. We here point out that the correlation shown in Fig. 1 is based on single crystal Zeeman NQR spectroscopy only.

There is a rather simple relation between the ionic character $\mathrm{i}$ of a single bond $\mathrm{A}-\mathrm{B}$ and the electronegativity of the atoms involved, $X_{\mathrm{A}}$ and $X_{\mathrm{B}}$ [51]:

$$
i=1 / 2\left|X_{\mathrm{A}}-X_{\mathrm{B}}\right| \text {. }
$$

Figure 2 shows the results for halogenides $\mathrm{AB}$ reported by Townes and Dailey [10] and by Gordy [51]. The ionic character of the bond $\mathrm{A}-\mathrm{B}$ was calculated by the authors from microwave spectroscopic data.

The relation (7) can be successfully applied in many cases if the electronegativities are kown. Several NQRstudies (experimental and theoretical) on the correlation between the ionic character $i$ of a bond and the electronegativity difference of the partners are reported, e.g. for compounds $\mathbf{M} X_{4}, \mathbf{M}=$ group IVaelement, $\mathrm{B}=$ halogen atom [52-54], see also [6], [8]. Not very advanced is the theory of group electronegativities. Anyway, tables of empirical data are scare. Since, however, the empirical correlations show that the ionic character of a bond $\mathrm{A}-\mathrm{R}$ increases with the sum of the electronegativities of the atoms in a complex group $\mathrm{R}$, it may be worthwhile to determine from an experimental NQR-ionicity correlation group electronegativities. Taking advantage of (7), Miyagawa [55] has correlated $e \Phi_{z z} Q h^{-1}\left({ }^{35} \mathrm{Cl}\right)$ measured on aliphatic chlorohydrocarbons with calculated electric dipole moments $\mu$ and found a linear correlation

$$
e \Phi_{z z} Q h^{-1}\left({ }^{35} \mathrm{Cl}\right)=a+b|\mu| \text {. }
$$


Table 1. $e \Phi_{z z} Q h^{-1}\left({ }^{35} \mathrm{Cl}\right)$ (in $\left.\mathrm{MHz}\right)$ and $\eta\left({ }^{35} \mathrm{Cl}\right)$ for chlorobenzene derivatives found from single crystal Zeeman-split NQR spectroscopy. All data used, were measured at room temperature. The double bond character $\pi$ is calculated with the aid of (5), and then $i$ by (6). Additionally the $x_{i}$-values (in MHz) [14, 15, 16] are listed. Not included are low temperature investigations on para-dichlorobenzene [17], ortho-dichlorobenzene [18], hexachlorobenzene [19], 1,2,3-trichlorobenzene [20], parachloroaniline [21], and parachlorobenzyl chloride [21].

\begin{tabular}{|c|c|c|c|c|c|c|c|c|c|c|c|c|c|c|c|c|}
\hline No. & Substance & & $e^{2} q Q h^{-1}$ & $\eta$ & $\sum_{i} x_{i}$ & $\pi \cdot 10^{2}$ & $i \cdot 10^{2}$ & Ref. & No. & Substance & $e^{2} q Q h^{-1}$ & $\eta$ & $\sum_{i} x_{i}$ & $\pi \cdot 10^{2}$ & $i \cdot 10^{2}$ & Ref. \\
\hline 1 & & 72.412 & 0.125 & 2.034 & 4.8 & $20.7^{\mathrm{a}}$ & {$[22]$} & 17 & $5-\mathrm{Cl}-2-\mathrm{OCH}_{3} \mathrm{C}_{6} \mathrm{H}_{3} \mathrm{NH}_{2}$ & 67.574 & 0.065 & 0.096 & 2.3 & 26.7 & [37] \\
\hline \multirow[t]{3}{*}{2} & \multirow{3}{*}{\multicolumn{2}{|c|}{$1,3,5-\mathrm{Cl}_{3} \mathrm{C}_{6} \mathrm{H}_{3}$}} & 69.946 & 0.09 & 0.998 & 3.3 & $23.8^{\mathrm{a}}$ & {$[23]$} & 18 & $2,6-\mathrm{Cl}_{2}-4-\mathrm{NO}_{2} \mathrm{C}_{6} \mathrm{H}_{2} \mathrm{NH}_{2}$ & 69.772 & 0.165 & 0.966 & 6.1 & $23.1^{\mathrm{a}}$ & [38] \\
\hline & & & 70.450 & 0.11 & 0.998 & 4.1 & 23.1 & & & & 70.578 & 0.155 & 0.966 & 5.8 & 22.4 & \\
\hline & & & 70.920 & 0.12 & 0.998 & 4.5 & 22.4 & & 19 & $2,6-\left(\mathrm{NO}_{2}\right)_{2} \mathrm{C}_{6} \mathrm{H}_{3} \mathrm{Cl}$ & 75.915 & 0.170 & 4.398 & 6.8 & 16.3 & [39] \\
\hline 3 & \multicolumn{2}{|l|}{$4-\mathrm{ClC}_{6} \mathrm{H}_{4} \mathrm{CO}_{2} \mathrm{H}$} & 68.327 & 0.08 & 0.409 & 2.9 & 25.7 & {$[24]$} & 20 & $3-\mathrm{Cl}-\mathrm{C}_{6} \mathrm{H}_{4} \mathrm{NHCOCH}_{3}$ & 68.196 & 0.03 & 0.373 & 1.1 & 26.5 & [40] \\
\hline \multirow[t]{5}{*}{4} & \multirow[t]{5}{*}{$\mathrm{C}_{6} \mathrm{Cl}_{5} \mathrm{OH}$} & $\mathrm{Cl}^{(3)}$ & 75.689 & 0.167 & 3.858 & 6.7 & $16.6^{\mathrm{a}}$ & {$[25]$} & & & 67.281 & 0.09 & 0.373 & 3.2 & 26.7 & \\
\hline & & $\mathrm{Cl}^{(4)}$ & 75.073 & 0.185 & 3.513 & 7.4 & 17.0 & & 21 & $3,5-\mathrm{Cl}_{2} \mathrm{C}_{6} \mathrm{H}_{3} \mathrm{NO}_{2}$ & 71.948 & 0.105 & 1.436 & 4.0 & 21.5 & [41] \\
\hline & & $\mathrm{Cl}^{(2)}$ & 75.084 & 0.164 & 3.513 & 6.5 & 17.3 & & 22 & $2,5-\mathrm{Cl}_{2} \mathrm{C}_{6} \mathrm{H}_{3} \mathrm{NHCOCH}_{3}$ & & & & & & \\
\hline & & $\mathrm{Cl}^{(1)}$ & 73.635 & 0.163 & 2.982 & 6.4 & 18.9 & & & $\mathrm{Cl}^{(2)}$ & 70.405 & 0.04 & 1.086 & 1.5 & 23.9 & [42] \\
\hline & & $\mathrm{Cl}^{(5)}$ & 73.218 & 0.100 & 2.982 & 3.9 & 20.2 & & & $\mathrm{Cl}^{(5)}$ & 69.194 & 0.04 & 0.702 & 1.5 & 25.3 & \\
\hline \multirow[t]{2}{*}{5} & \multirow{2}{*}{$\mathrm{C}_{6} \mathrm{Cl}_{4}(\mathrm{OH})_{2}$} & $\mathrm{Cl}^{(1)}$ & 73.381 & 0.09 & 2.756 & 3.5 & $20.1^{\text {a }}$ & {$[26]$} & 23 & $2,5-\mathrm{Cl}_{2}-4-\mathrm{NO}_{2} \mathrm{C}_{6} \mathrm{H}_{2} \mathrm{NH}_{2}$ & & & & & & \\
\hline & & $\mathrm{Cl}^{(2)}$ & 73.713 & 0.13 & 2.756 & 5.1 & 19.2 & & & $\mathrm{Cl}^{(2)}$ & 70.391 & 0.020 & 0.796 & 0.7 & 24.2 & [43] \\
\hline \multirow[t]{2}{*}{6} & \multirow[t]{2}{*}{$2,5-\mathrm{Cl}_{2} \mathrm{C}_{6} \mathrm{H}_{3} \mathrm{NH}_{2}$} & $\mathrm{Cl}^{(2)}$ & 67.746 & 0.069 & 0.029 & 2.5 & $26.5^{\mathrm{a}}$ & {$[27]$} & & $\mathrm{Cl}^{(5)}$ & 70.656 & 0.055 & 2.883 & 2.1 & 23.5 & \\
\hline & & $\mathrm{Cl}^{(5)}$ & 67.971 & 0.066 & 0.314 & 2.4 & 26.3 & & 24 & $2,3,6-\mathrm{Cl}_{3} \mathrm{C}_{6} \mathrm{H}_{2} \mathrm{OCOCH}_{3}$ & & & & & & \\
\hline 7 & $1,4-\mathrm{Cl}_{2} \mathrm{C}_{6} \mathrm{H}_{4}$ & & 68.477 & 0.073 & 0.329 & 2.6 & $25.6^{\mathrm{a}}$ & {$[28]$} & & $\mathrm{Cl}^{(3)}$ & 71.824 & 0.1037 & 2.000 & 3.9 & $21.6^{\mathrm{a}}$ & [44] \\
\hline 8 & $4-\mathrm{ClC}_{6} \mathrm{H}_{4} \mathrm{NH}_{2}$ & & 67.507 & 0.049 & -0.470 & 1.8 & 27.0 & [28] & & $\mathrm{Cl}^{(6)}$ & 71.977 & 0.1015 & 1.843 & 3.8 & 21.5 & \\
\hline \multirow[t]{2}{*}{9} & \multirow[t]{2}{*}{$2,5-\mathrm{Cl}_{2} \mathrm{C}_{6} \mathrm{H}_{3} \mathrm{NO}_{2}$} & $\mathrm{Cl}^{(2)}$ & 74.310 & 0.11 & 2.975 & 4.3 & 18.8 & [29] & & $\mathrm{Cl}^{(2)}$ & 72.591 & 0.1423 & 2.720 & 5.5 & 20.3 & \\
\hline & & $\mathrm{Cl}^{(5)}$ & 70.864 & 0.09 & 1.266 & 3.4 & 22.8 & & 25 & 3-Cl-4- $\mathrm{OCH}_{3} \mathrm{C}_{6} \mathrm{H}_{3} \mathrm{NH}_{2}$ & 69.357 & 0.085 & 0.666 & 3.1 & 24.5 & {$[45]$} \\
\hline \multirow[t]{2}{*}{10} & \multirow{2}{*}{\multicolumn{2}{|c|}{$4-\mathrm{ClC}_{6} \mathrm{H}_{4} \mathrm{OH}$}} & 68.183 & 0.071 & 0.249 & 2.6 & 26.0 & {$[30]$} & 26 & $2,6-\mathrm{Cl}_{2} \mathrm{C}_{6} \mathrm{H}_{3} \mathrm{NHCOCH}_{3}($ & (II) & & & & & \\
\hline & & & 68.595 & 0.096 & 0.249 & 3.5 & 25.2 & & & $\mathrm{Cl}^{(2)}$ & 70.435 & 0.1214 & 1.256 & 4.5 & $22.9^{a}$ & {$[46]$} \\
\hline \multirow[t]{2}{*}{11} & \multirow{2}{*}{\multicolumn{2}{|c|}{ 4-Cl-3- $\mathrm{CH}_{3} \mathrm{C}_{6} \mathrm{H}_{3} \mathrm{OH}$}} & 68.644 & 0.07 & -0.143 & 2.5 & 25.5 & {$[31]$} & & $\mathrm{Cl}^{(6)}$ & 70.244 & 0.1013 & 1.256 & 3.8 & 23.4 & {$[40]$} \\
\hline & & & 68.117 & 0.12 & -0.143 & 4.3 & 25.5 & & & (Phase I) & 69.674 & 0.1293 & 1.256 & 4.8 & 23.7 & \\
\hline \multirow[t]{4}{*}{12} & \multicolumn{2}{|c|}{$2,4,6-\mathrm{Cl}_{3} \mathrm{C}_{6} \mathrm{H}_{2} \mathrm{OCH}_{3}$} & & & & & & & & $\mathrm{Cl}^{(6)}$ & 68.890 & 0.1307 & 1.256 & 4.8 & 24.5 & \\
\hline & & $\mathrm{p}-\mathrm{Cl}$ & 70.019 & 0.21 & 1.186 & 7.8 & 22.3 & {$[32]$} & 27 & 1-Cl-3- $\mathrm{NO}_{2} \mathrm{C}_{6} \mathrm{H}_{4}$ & 69.745 & 0.1091 & 0.937 & 4.0 & $23.8^{\mathrm{a}}$ & {$[47]$} \\
\hline & & $\mathrm{o}-\mathrm{Cl}$ & 71.369 & 0.14 & 1.756 & 5.3 & 21.7 & & 28 & $1,2-\mathrm{Cl}_{2}-3-\mathrm{NO}_{2} \mathrm{C}_{6} \mathrm{H}_{3}$ & & & & & & \\
\hline & \multirow{2}{*}{$3,4-\mathrm{Cl}_{2} \mathrm{C}_{6} \mathrm{H}_{3} \mathrm{NO}_{2}$} & $\mathrm{O}-\mathrm{Cl}$ & 72.236 & 0.15 & 1.756 & 5.7 & 20.6 & & & $\mathrm{Cl}^{(1)}$ & 71.892 & 0.1287 & 2.143 & 4.9 & $21.3^{\mathrm{a}}$ & [48] \\
\hline 13 & & $\mathrm{Cl}^{(4)}$ & 72.683 & $\begin{array}{l}0.08 \\
0.08\end{array}$ & 2.143 & 3.1 & 21.0 & [33] & & $\mathrm{Cl}^{(2)}$ & 75.436 & 0.1525 & 3.852 & 6.1 & 17.1 & \\
\hline & \multicolumn{2}{|c|}{ 4-Cl-2- $\mathrm{NO}_{2} \mathrm{C}_{6} \mathrm{H}_{3} \mathrm{O}$} & $\begin{array}{l}71.903 \\
69.914\end{array}$ & $\begin{array}{l}0.08 \\
0.17\end{array}$ & $\begin{array}{l}1.787 \\
1.186\end{array}$ & $\begin{array}{l}3.0 \\
6.3\end{array}$ & $\begin{array}{l}21.8 \\
22.9\end{array}$ & & 29 & 1-Cl-2,4- $\left(\mathrm{NO}_{2}\right)_{2} \mathrm{C}_{7} \mathrm{H}_{3}$ & 74.287 & 0.1636 & 3.227 & 6.4 & $18.2^{\mathrm{a}}$ & [49] \\
\hline \multirow{3}{*}{15} & \multirow{3}{*}{$2,4,6-\mathrm{Cl}_{3} \mathrm{C}_{6} \mathrm{H}_{2} \mathrm{CN}$} & $\mathrm{Cl}^{(4)}$ & $\begin{array}{l}69.914 \\
71.208\end{array}$ & 0.130 & $\begin{array}{l}1.186 \\
1.476\end{array}$ & $\begin{array}{l}0.3 \\
4.9\end{array}$ & $22.0^{a}$ & $\begin{array}{l}{[34]} \\
{[35]}\end{array}$ & 30 & $1,2,4,5-\mathrm{Cl}_{4}-3,6-\left(\mathrm{NO}_{2}\right)_{2} \mathrm{C}_{6}$ & 76.937 & 0.1207 & 4.723 & 4.9 & $15.8^{\mathrm{a}}$ & [50] \\
\hline & & $\mathrm{Cl}^{(2)}$ & 72.592 & 0.128 & $\begin{array}{l}1.4 / 0 \\
2.114\end{array}$ & $\begin{array}{l}4.9 \\
4.9\end{array}$ & $\begin{array}{l}22.0 \\
20.5\end{array}$ & [3ग] & 31 & $1,3,5-\mathrm{Cl}_{3}-2,4-\left(\mathrm{NO}_{2}\right)_{2} \mathrm{C}_{6} \mathrm{H}$ & & & & & & \\
\hline & & $\mathrm{Cl}^{(6)}$ & 73.717 & 0.116 & 2.114 & 4.5 & 19.4 & & & $C^{(1)}$ & 74.672 & 0.1097 & 3.310 & 4.3 & $18.4^{\mathrm{a}}$ & {$[50]$} \\
\hline 16 & 2,4- $\mathrm{Cl}_{2} \mathrm{C}_{6} \mathrm{H}_{3} \mathrm{NHCC}$ & $\mathrm{OCH}_{3}$ & & & & & & & & $\mathrm{Cl}^{(3)}$ & 77.167 & 0.0969 & 4.502 & 4.0 & 15.9 & \\
\hline & & $\mathrm{Cl}^{(2)}{ }^{3}$ & 70.199 & 0.07 & 1.256 & 2.6 & 23.8 & [36] & & $\mathrm{Cl}^{(5)}$ & 74.422 & 0.1143 & 3.310 & 4.5 & 18.7 & \\
\hline & & $\mathrm{Cl}^{(4)}$ & 68.534 & 0.07 & 0.694 & 2.5 & 25.6 & & & & & & & & & \\
\hline
\end{tabular}

a Crystal structure is reported in literature. 


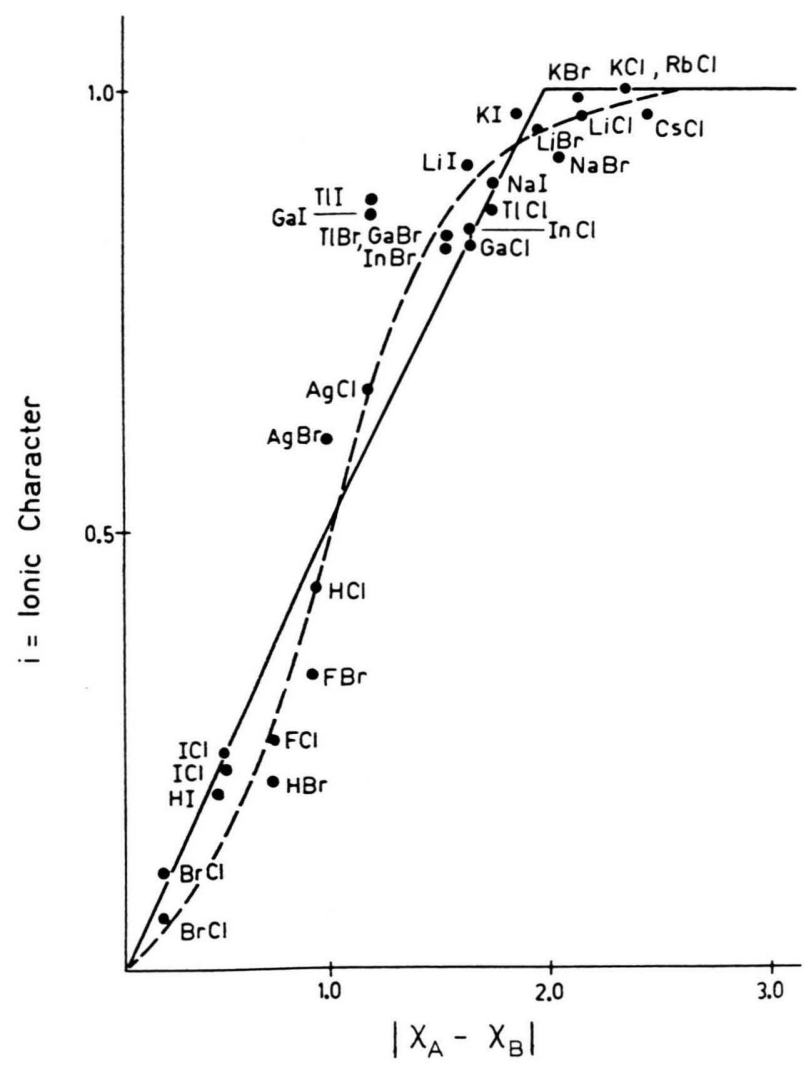

Fig. 2. Ionic character of the bond $\mathbf{A}-\mathbf{B}$ in diatomic molecules as a function of the electronegativity difference $\left|X_{\mathrm{A}}-X_{\mathrm{B}}\right|$ of the partners A and B [10], [51].

Equation (8) is, however, only a first order approximation, as many correlations are. Modifications of this relation have been observed; they result from crystal field effects (see below) and, as with the melting points of alkanes, the influence of even-odd number of carbon atoms appears in ${ }^{35} \mathrm{Cl}-\mathrm{NQR}[56,57]$.

\section{$N Q R$ and Hammett $\sigma$ Parameters}

Probably the most frequently applied correlation of NQR data with chemical bond parameters is the relation between the NQR frequency, respectively the NQCC, and the Hammett $\sigma$ parameter. $\sigma$ is determined from equilibrium, or from reaction rate constants $K$ via

$$
\log \left(K / K_{0}\right)=\Gamma \sigma
$$

$\Gamma$ is characteristic for the reaction under investigation (dissociation of an acid, saponification of an ester, etc.). $\sigma$ characterizes the substituent in a molecule. The Hammett model was originally put foreward for applications to substitutions on the aromatic ring and there to meta- and para-substitution. Meal [58], in the spring days of NQR, first correlated Hammett $\sigma$ with the NQR frequencies and found a linear relation

$$
v\left({ }^{35} \mathrm{Cl}\right)=a+b \sigma
$$

for monochlorobenzenes $\mathrm{ClC}_{6} \mathrm{H}_{4} \mathrm{X}$. Bray $[59,60]$ extended the correlation to monobromobenzenes, and then it was generalized to polyhalogenobenzenes by Bray and his colleagues and by others [61-64]. For the large number of compounds

$$
v\left({ }^{35} \mathrm{Cl}\right) / \mathrm{MHz}=34.826+1.024 \sum_{i} \sigma_{i}
$$

resulted [61]. The interpretation of (11) is:

1) The change of $v\left({ }^{35} \mathrm{Cl}\right)$ (and $v\left({ }^{79,81} \mathrm{Br}\right), v\left({ }^{127} \mathrm{I}\right)$, etc.) is characteristic for a certain substituent; it is constant and independent of the presence of other substituents on the benzene ring. The effect of multiple substitution is additive (additivity rule).

2) In contrast to the Hammett equation, the additivity rule holds for substituents ortho to the atom, which incorporates the NQR nucleus, too.

Biedenkapp and Weiss [14] have introduced substituent parameters which are derived directly from $v\left({ }^{35} \mathrm{Cl}\right)$

$$
v\left({ }^{35} \mathrm{Cl}\right)=v_{0}+\sum_{i} \varkappa_{i},
$$

and applied (12) to a large number of benzene derivatives. The logic of such a definition of a correlation parameter lies in the fact that Hammett $\sigma$ is derived from reaction rates, whereas the kappa values are true ground state parameters (NQR is a measurement on a ground state molecule, respectively solid). Extensions of the $v(\mathrm{NQR})-\sigma$-relation for heterocyclic compounds and for aliphatic systems have been reported in $[65-70]$.

In case of $I=3 / 2$, from "common" NQR spectroscopy the frequency $v(I=3 / 2)$ is the observable. Since for ${ }^{35,37} \mathrm{Cl}$ and for ${ }^{79,81} \mathrm{Br}$ single bonds $\mathrm{R}$-halogen is the frequent connections, $\eta$ is mostly $<0.2$, and from

$$
v(I=3 / 2)=(1 / 2) e \Phi_{z z} Q h^{-1}\left(1+\eta^{2} / 3\right)^{1 / 2}
$$

$v \approx(1 / 2) e \Phi_{z z} Q h^{-1}$ follows. For all other quadrupolar nuclei, $I=1$ and $I \geqq 3 / 2, e \Phi_{z z} Q h^{-1}$ is available from the experiment on polycrystalline material.

The model of Taft, to divide $\sigma$ in an inductive $\left(\sigma_{\mathrm{I}}\right)$ and a resonance $\left(\sigma_{\mathbf{R}}\right)$ term, and its application to NQR 


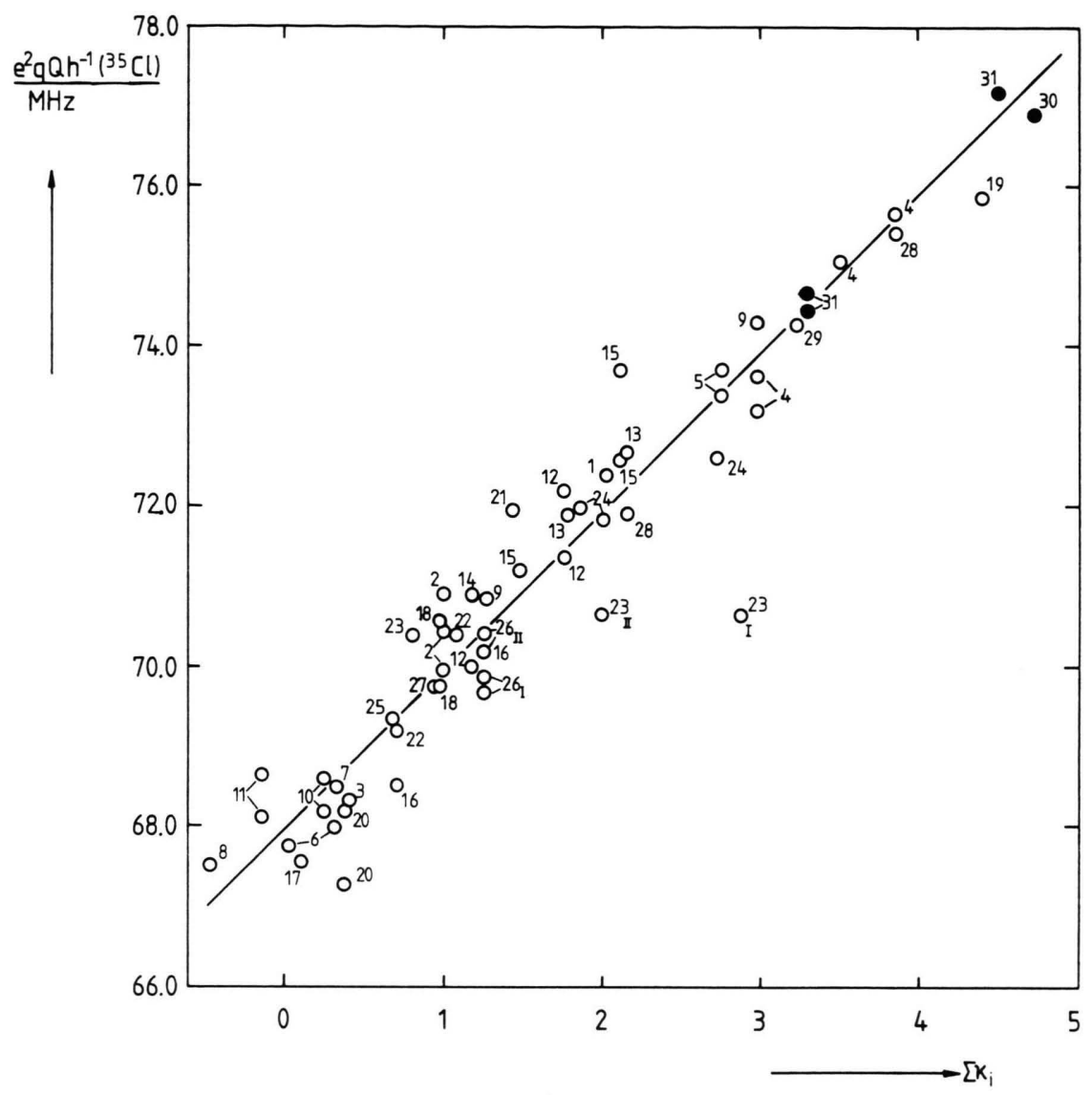

Fig. 3. Nuclear quadrupole coupling constants $e \Phi_{z z} Q h^{-1}$ $\left({ }^{35} \mathrm{Cl}\right)$ of substituted chlorobenzenes vs. the substitution parameter $\varkappa_{i}$. The numbers given in the Figure correspond to the numbering in Table 1. The least squares fit gives $\left(\Phi_{z z} \equiv e q\right)$ $e \Phi_{z z} Q h^{-1}\left({ }^{35} \mathrm{Cl}\right) / \mathrm{MHz}$ $=67.974+1.9 \sum_{i} x_{i}$.

is discussed in literature at lengths, see e.g. $[14,6,8]$.

We have a look on an $e \Phi_{z z} Q h^{-1}\left({ }^{35} \mathrm{Cl}\right)-\chi_{i}$ correlation. For the compounds listed in Table 1, the $x_{i}$ values calculated from the data in $[15,16]$ are given, too. In Fig. 3 the $e \Phi_{z z} Q h^{-1}\left({ }^{35} \mathrm{Cl}\right)$ are plotted vs. $\sum_{i} \chi_{i}$. The correlation found is quite satisfying. As in Fig. 1, the correlation given in Fig. 3 is based on single crystal Zeeman NQR spectroscopy.

It is interesting to compare Fig. 1 with Fig. 3. The striking feature is the stronger scattering of the data (the less satisfying correlation) shown in Fig. 3 compared to Fig. 1. Particularly the sum of the $x_{i}$ for compounds no. 20 and 23 (Table 1) is deviating from the correlation line. The cause may be twofold,

a) the $x_{i}$ for several substituents relay on a few measurements only and therefore the error may be large and

b) the $\varkappa_{i}$ for groups which have a rotational degree of freedom with respect to the aromatic ring may depend on a twist angle $\alpha$ with respect to this plane. The same arguments hold for the $\sigma$ values.
The correlation $e \Phi_{z z} Q h^{-1}=f($ Hammett $\sigma$ ) is not restricted to single bond atoms, working quite well e.g. for nitrogen. This is shown in Fig. 4, where $e \Phi_{z z} Q h^{-1}\left({ }^{14} \mathrm{~N}\right)$ is plotted vs. $\sum \sigma_{i}$ for a considerable number of molecules. The numbered compounds in Fig. 4 are listed in Table 2.

In summary, we can say that nuclear quadrupole resonance frequencies (or $e \Phi_{z z} Q h^{-1}$ ) correlate well with empirical bond parameters, such as ionicity, electronegativity, Hammett $\sigma$, and the $\varkappa$-parameters.

\section{NQR and Bond Geometry}

As already discussed, the direct connection of the EFG tensor with another observable is the dependence of $e \Phi_{z z} Q h^{-1}$ on the charge distribution around the nucleus considered. The most simple outcome of (1) is, in "pure" ionic crystals, the point charge model which, however, has to be modified by the antishielding (Sternheimer factor). Nevertheless, $\Phi_{z z}$ is a func- 


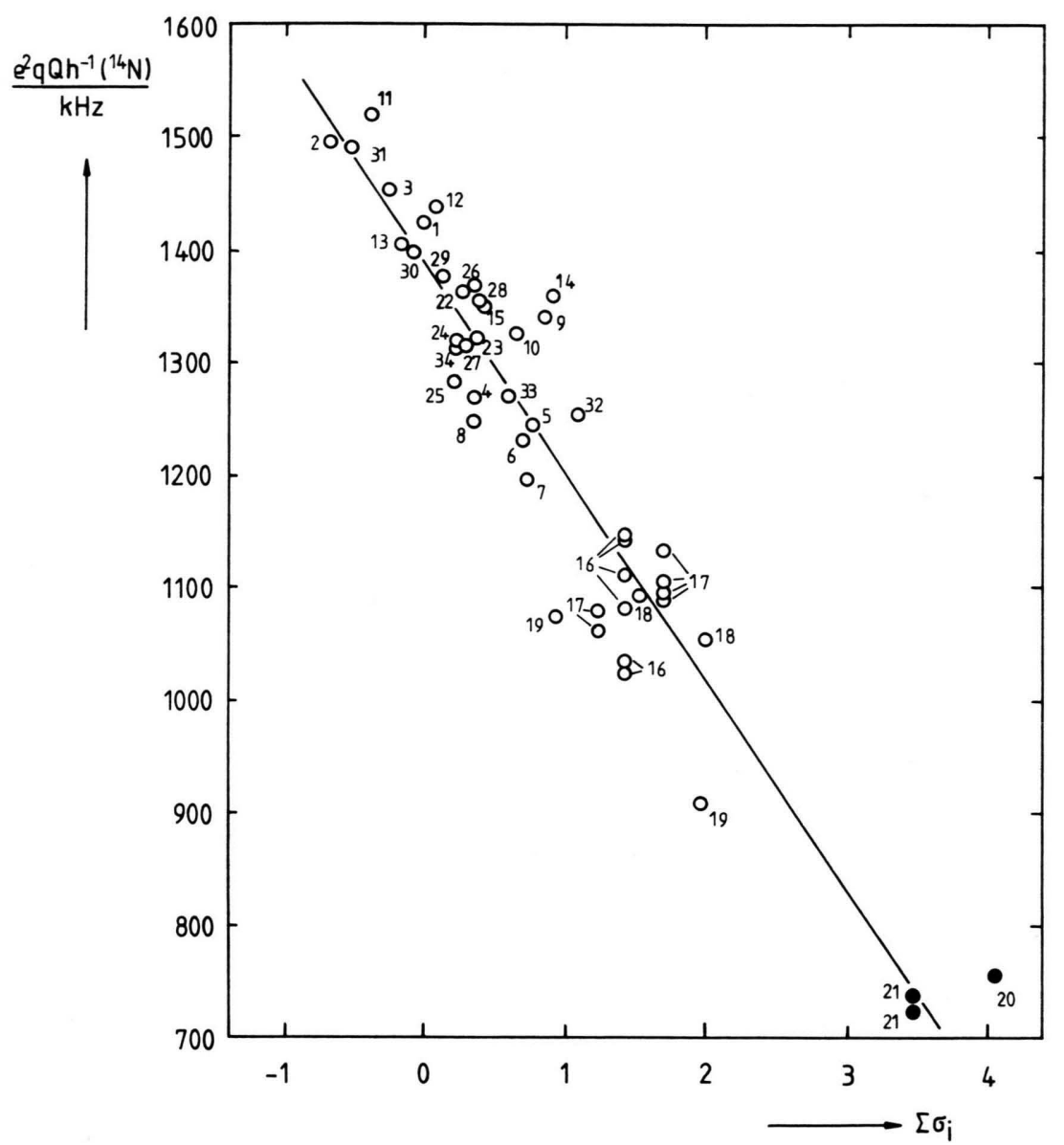

Fig. 4. Nuclear quadrupole coupling constant $e \Phi_{z z} Q h^{-1}\left({ }^{14} \mathrm{~N}\right)$ of substituted nitrobenzenes vs. Hammett- $\sigma$ parameters. The numbers given in the Figure correspond to the numbering in Table 2. The least squares fit gives $\left(\Phi_{z z} \equiv e q\right)$ $e \Phi_{z z} Q h^{-1}\left({ }^{14} \mathrm{~N}\right) / \mathrm{MHz}$ $=1.388-0.18 \sum_{i} \sigma_{i}$.

tion of the distance $r$ of all the charges acting via the EFG at the nucleus, and $\Phi_{z z}=f\left(r^{-3}\right)$.

It is appropriate to apply (1) to molecules condensed into a solid, too, and to relate simply the EFG (or in first approximation the NQR frequency) to the intramolecular distance $d(\mathrm{R}-\mathrm{X})$, where $\mathrm{X}$ is the quadrupolar nucleus and $\mathrm{R}$ the rest of the molecule. In case $\mathrm{X}$ is a group of atoms, e.g. $-\mathrm{NO}_{2}$, the orientation of this group with respect to $\mathrm{R}$ may also influence the acting EFGT.

\section{$N Q R$ and Bond Distances}

To correlate NQR with bond distances, the crystal structure of the compound under investigation must be known. This is a somewhat limiting condition; quite often the structure one is looking for is not available in literature. Furthermore, the difficulty lies in the accuracy of bond distance determinations. As an example, we consider $\mathrm{C}-\mathrm{Cl}$ bonds in the group $-\mathrm{CCl}_{3}\left(\mathrm{sp}^{3}-\right.$ carbon). In the molecule trichloroethylidene trichlorolactic ester (Chloralide), $\mathrm{Cl}_{3} \mathrm{CCHOCOCHOCCl}$,

there are two $\mathrm{CCl}_{3}$ groups; the six chlorines are crystallographically independent, that is, one finds six distances $d(\mathrm{C}-\mathrm{Cl})$ [93]. They are observed in the range $175.8 \leqq d / \mathrm{pm} \leqq 176.5( \pm 0.4) . e \Phi_{z z} Q h^{-1}\left({ }^{35} \mathrm{Cl}\right)$ at $T=21{ }^{\circ} \mathrm{C}$ is in the range $76.053 \leqq e \Phi_{z z} Q h^{-1}\left({ }^{35} \mathrm{Cl}\right) /$ $\mathrm{MHz} \leqq 78.790( \pm 0.006)$ [94]. It is easy to see that the spread in $d(\mathrm{C}-\mathrm{Cl})$ is $0.7 \mathrm{pm} \pm 0.4 \mathrm{pm}$ whereas the spread in $e \Phi_{z z} Q h^{-1}\left({ }^{35} \mathrm{Cl}\right)$ is $2.737 \pm 0.006 \mathrm{MHz}$. A correlation $e \Phi_{z z} Q h^{-1}\left({ }^{35} \mathrm{Cl}\right)=f\left(1 / d^{3}(\mathrm{C}-\mathrm{Cl})\right)$ was tried, but with very little success as can be seen in Figure 5.

It seems to be rather difficult, too, to correlate $d(\mathrm{C}-\mathrm{Cl})$ in benzenoid systems with $v\left({ }^{35} \mathrm{Cl}\right)$ or with $e \Phi_{z z} Q h^{-1}\left({ }^{35} \mathrm{Cl}\right)$.

A different situation occurs if one considers bond distances $d(\mathrm{C}-\mathrm{Cl})$ where $\mathrm{C}$ is a true $\mathrm{sp}^{2}$-carbon. 


\begin{tabular}{|c|c|c|c|c|c|c|}
\hline No. & Compound & $e \Phi_{z z} Q h^{-1}\left({ }^{14} \mathrm{~N}\right)$ & $\eta\left({ }^{14} \mathrm{~N}\right)$ & $\alpha$ & $\sum \sigma$ & Ref. \\
\hline 1 & $\mathrm{C}_{6} \mathrm{H}_{5} \mathrm{NO}_{2}$ & 1425 & 0.404 & 0 & 0 & {$[71,72]$} \\
\hline 2 & $4-\left(\mathrm{NO}_{2}\right) \mathrm{C}_{6}^{2} \mathrm{H}_{4} \mathrm{NH}_{2}$ & 1493 & 0.292 & 1.9 & -0.66 & {$[71,73]$} \\
\hline 3 & $3-\left(\mathrm{NO}, \mathrm{C}_{\mathrm{H}} \mathrm{NH}_{2}\right.$ & 1453 & 0.374 & 20 & -0.15 & {$[71.74]$} \\
\hline 4 & $3-\mathrm{ClC}_{6} \mathrm{H}_{4} \mathrm{NO}$ & 1271 & 0.356 & 0 & 0.37 & {$[71,47]$} \\
\hline 5 & $1,4-\left(\mathrm{NO}_{2}\right)_{2} \mathrm{C}_{6} \mathrm{H}_{4}$ & 1246 & 0.326 & 11.0 & 0.78 & {$[71,75]$} \\
\hline 6 & $1,3-\left(\mathrm{NO}_{2}\right)_{2} \mathrm{C}_{6} \mathrm{H}_{4}^{4}$ & 1232 & 0.360 & 13.0 & 0.71 & {$[71,76]$} \\
\hline 7 & $4-\left(\mathrm{NO}_{2}\right) \mathrm{C}_{6} \mathrm{H}_{4} \mathrm{CO}_{2} \mathrm{H}$ & 1196 & 0.284 & 13.7 & 0.73 & {$[77,78]$} \\
\hline 8 & $3-\left(\mathrm{NO}_{2}\right) \mathrm{C}_{6} \mathrm{H}_{4}^{4} \mathrm{CO}_{2}^{2} \mathrm{H}$ & 1249 & 0.375 & $\begin{array}{r}5.3 \\
21.7\end{array}$ & 0.37 & {$[77,79]$} \\
\hline 9 & 4- $\left(\mathrm{NO}_{2}\right) \mathrm{C}_{6} \mathrm{H}_{4} \mathrm{COCH}_{3}$ & 1341 & 0.361 & 3.6 & 0.87 & {$[77,80]$} \\
\hline 10 & $4-\left(\mathrm{NO}_{2}\right) \mathrm{C}_{6} \mathrm{H}_{4} \mathrm{CN}$ & 1327 & 0.363 & 10.3 & 0.66 & {$[77,81]$} \\
\hline 11 & $4-\left(\mathrm{NO}_{2}\right) \mathrm{C}_{6} \mathrm{H}_{4} \mathrm{OH}$ & 1523 & 0.357 & 1.5 & -0.37 & {$[77,82]$} \\
\hline 12 & $3-\left(\mathrm{NO}_{2}\right) \mathrm{C}_{6} \mathrm{H}_{4} \mathrm{OH}$ & 1469 & 0.347 & 0.5 & 0.12 & {$[77,83]$} \\
\hline 13 & $4-\left(\mathrm{NO}_{2}\right) \mathrm{C}_{6}^{0} \mathrm{H}_{4}^{4} \mathrm{CH}_{3}$ & 1406 & 0.408 & 3.0 & -0.17 & {$[77,84]$} \\
\hline $13 \mathrm{a}$ & 4- $\left(\mathrm{NO}_{2}\right) \mathrm{C}_{6} \mathrm{H}_{4} \mathrm{CH}_{3}$ & 1340 & 0.408 & & & {$[77 \mathrm{a}, 84]$} \\
\hline 14 & $2-\left(\mathrm{NO}_{2}\right) \mathrm{C}_{6} \mathrm{H}_{4} \mathrm{OH}^{3}$ & 1363 & 0.307 & 1.6 & 0.89 & {$[77,85]$} \\
\hline 15 & $1,3,5-\left(\mathrm{CH}_{3}^{\circ}\right)_{3} \stackrel{\mathrm{C}}{6}_{6} \mathrm{H}_{2}\left(\mathrm{NO}_{2}\right)$ & 1353 & 0.163 & 66.4 & 0.41 & {$[86,87]$} \\
\hline \multirow[t]{6}{*}{16} & $1,3,5-\left(\mathrm{NO}_{2}\right)_{3} \mathrm{C}_{6} \mathrm{H}_{3}$ & 1145 & 0.352 & 10.0 & 1.42 & {$[88,89]$} \\
\hline & & 1140 & 0.359 & 10.0 & 1.42 & \\
\hline & & 1111 & 0.355 & 5.0 & 1.42 & \\
\hline & & 1083 & 0.351 & 3.0 & 1.42 & \\
\hline & & 1035 & 0.416 & 8.0 & 1.42 & \\
\hline & & 1024 & 0.250 & 28.0 & 1.42 & \\
\hline \multirow[t]{6}{*}{17} & $2,4,6-\left(\mathrm{NO}_{2}\right)_{3} \mathrm{C}_{6} \mathrm{H}_{2} \mathrm{CH}_{3}$ & 1107 & 0.136 & 59.5 & 1.71 & {$[88,90]$} \\
\hline & orthorhomb. phase & 1134 & 0.167 & 50.9 & 1.71 & \\
\hline & & 1085 & 0.166 & 45.7 & 1.71 & \\
\hline & & 1095 & 0.200 & 41.3 & 1.71 & \\
\hline & & 1060 & 0.255 & 32.8 & 1.25 & \\
\hline & & 1079 & 0.284 & 22.3 & 1.25 & \\
\hline \multirow[t]{2}{*}{18} & $1,3,5-\left(\mathrm{NO}_{2}\right)_{3}-2,4-\left(\mathrm{CH}_{3}\right)_{2} \mathrm{C}_{6} \mathrm{H}$ & 1054 & 0.120 & 75.2 & 2.00 & {$[88,90]$} \\
\hline & & 1097 & 0.232 & 35.7 & 1.54 & \\
\hline \multirow[t]{2}{*}{19} & $2,4-\left(\mathrm{NO}_{2}\right)_{2} \mathrm{C}_{6} \mathrm{H}_{3} \mathrm{Cl}$ & 910 & 0.222 & 41.9 & 1.97 & {$[49,49]$} \\
\hline & & 1076 & 0.303 & 12.3 & 0.94 & \\
\hline 20 & $1,2,4,5-\mathrm{Cl}_{4} \mathrm{C}_{6}\left(\mathrm{NO}_{2}\right)_{2}$ & 757 & 0.025 & 90.0 & 4.04 & {$[50,92]$} \\
\hline \multirow[t]{2}{*}{21} & $1,3,5-\mathrm{Cl}_{3} \mathrm{C}_{6} \mathrm{H}-2,4-\left(\mathrm{NO}_{2}\right)_{2}$ & 722 & 0.069 & 79.7 & 3.46 & {$[50,92]$} \\
\hline & & 738 & 0.064 & 87.6 & 3.46 & \\
\hline 22 & $4-\mathrm{IC}_{6} \mathrm{H}_{4} \mathrm{NO}_{2}$ & 1363 & 0.364 & & 0.28 & {$[71,-]$} \\
\hline 23 & $3-\left(\mathrm{NO}_{2}\right)_{4}^{4} \mathrm{C}_{6} \mathrm{H}_{4} \mathrm{CHO}$ & 1324 & 0.366 & & 0.36 & {$[71,-]$} \\
\hline 24 & $4-\mathrm{ClC}_{6} \mathrm{H}_{4} \mathrm{NO}_{2}$ & 1321 & 0.406 & & 0.23 & {$[71,-]$} \\
\hline 25 & $4-\left(\mathrm{NO}_{2}\right) \mathrm{C}_{6} \mathrm{H}_{4} \mathrm{CHO}$ & 1284 & 0.333 & & 0.22 & {$[71,-]$} \\
\hline 26 & $3-\left(\mathrm{NO}_{2}\right) \mathrm{C}_{6} \mathrm{H}_{4} \mathrm{COCH}_{3}$ & 1369 & 0.391 & & 0.38 & {$[77,-]$} \\
\hline 27 & $4-\left(\mathrm{NO}_{2}\right) \mathrm{C}_{6} \mathrm{H}_{4} \mathrm{COOCH}_{3}$ & 1315 & 0.406 & & 0.31 & {$[77,-]$} \\
\hline 28 & $3-\left(\mathrm{NO}_{2}\right) \mathrm{C}_{6} \mathrm{H}_{4} \mathrm{COOCH}_{3}$ & 1357 & 0.389 & & 0.39 & {$[77,-]$} \\
\hline 29 & $3-\left(\mathrm{NO}_{2}\right) \mathrm{C}_{4}^{0} \mathrm{H}_{4}^{+} \mathrm{CH}=\mathrm{CHCO}_{2} \mathrm{H}$ & 1378 & 0.402 & & 0.14 & {$[77,-]$} \\
\hline 30 & $3-\left(\mathrm{NO}_{2}\right) \mathrm{C}_{6} \mathrm{H}_{4}^{4} \mathrm{CH}_{3}$ & 1400 & 0.400 & & -0.07 & {$[77,-]$} \\
\hline 31 & $2,6-\left(\mathrm{CH}_{3}\right)_{2}-4-\left(\mathrm{NO}_{2}\right) \mathrm{C}_{6} \mathrm{H}_{2} \mathrm{OH}$ & 1492 & 0.319 & & -0.51 & {$[77,-]$} \\
\hline 32 & 2-Cl-4- $\left(\mathrm{NO}_{2}\right) \mathrm{C}_{6} \mathrm{H}_{3} \mathrm{CO}_{2} \mathrm{H}$ & 1254 & 0.330 & & 1.10 & {$[77,-]$} \\
\hline 33 & 2-Cl-5-( $\left.\mathrm{NO}_{2}\right) \mathrm{C}_{6} \mathrm{H}_{3} \mathrm{COOH}$ & 1271 & 0.343 & & 0.60 & {$[77,-]$} \\
\hline 34 & $2-\mathrm{Cl}-4-\left(\mathrm{NO}_{2}\right) \mathrm{C}_{6} \mathrm{H}_{3} \mathrm{CH}_{3}$ & 1317 & 0.372 & & 0.20 & {$[77,-]$} \\
\hline
\end{tabular}

Table 2

$e \Phi_{z z} Q h^{-1}\left({ }^{14} \mathrm{~N}\right)$, in $\mathrm{kHz}$, and $\eta\left({ }^{14} \mathrm{~N}\right)$ for nitrobenzene derivatives. $\alpha$ is the twist angle of the $\mathrm{NO}_{2}$ group with respect to the benzene ring. No. $13 \mathrm{a}$, 19-21 are based on single crystal QFS-NMR studies at room temperature, all other on NQR measurements at $77 \mathrm{~K}$. The $\sigma$-values are taken from [16]. The first reference in the table belongs to the NQR- or QFSNMR work, the second to crystal structure determinations.

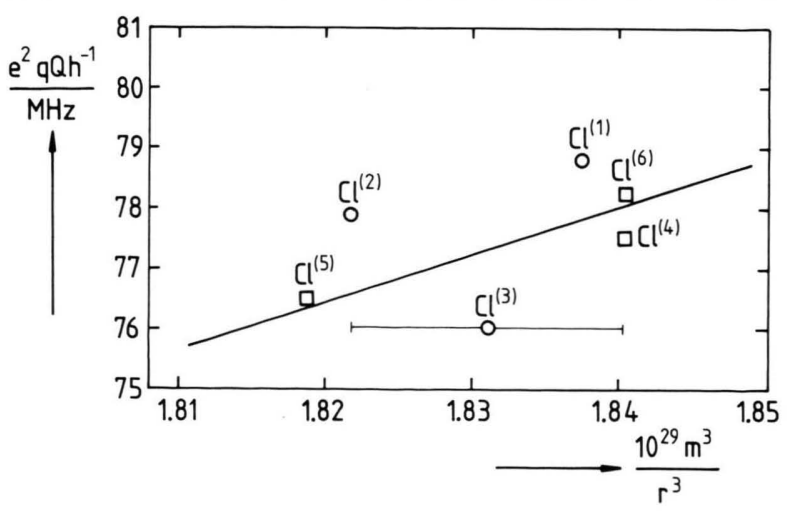

Fig. 5. $e \Phi_{z z} Q h^{-1}\left({ }^{35} \mathrm{Cl}^{(1-6)}\right)$ in trichloroethylidene trichlorolactic ester, $\mathrm{Cl}_{3} \mathrm{CCHOCOCHOCCl}$, versus the reciprocal third power of the bond distances $d\left(\mathrm{C}-\mathrm{Cl}^{(1-6)}\right)$. The mean error in $d^{-1}$ is shown in the graph as an error bar $\left(\Phi_{z z} \equiv e q\right)$. 


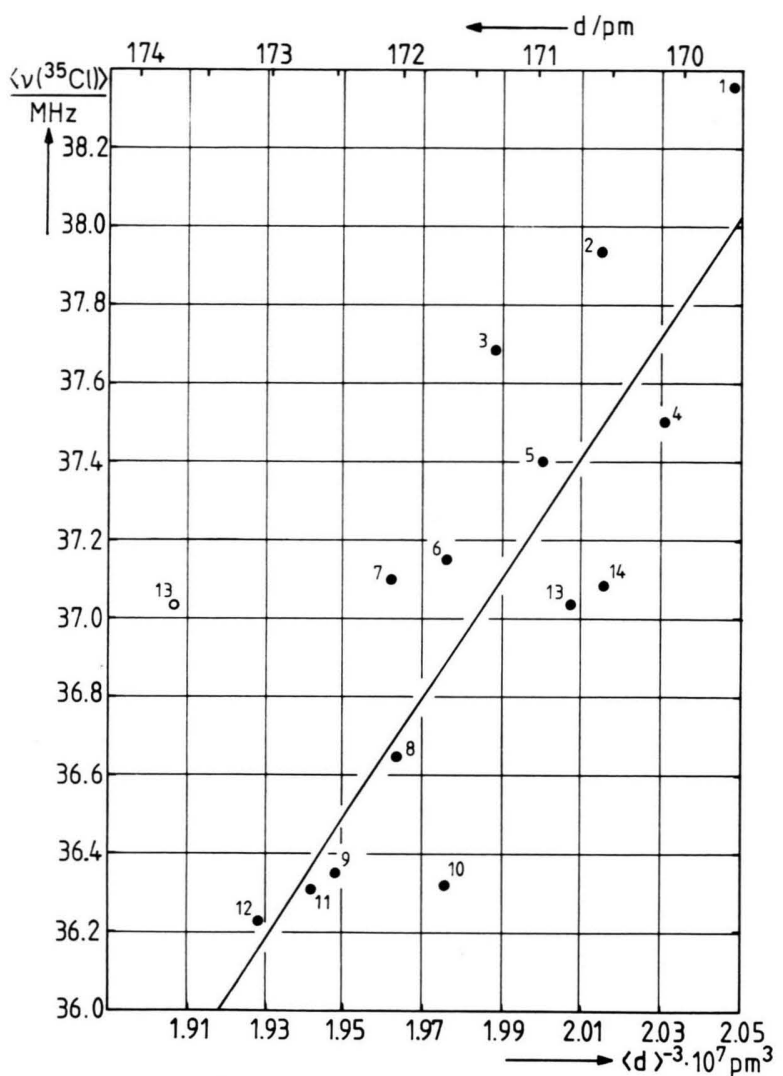

Fig. 6. Average ${ }^{35} \mathrm{Cl}$ NQR frequency $\left\langle v\left({ }^{35} \mathrm{Cl}\right)\right\rangle$ of chlorocyclohexadienones vs. $1 / d^{3}(\mathrm{C}-\mathrm{Cl})$ in these compounds. The open circle no. 13 corresponds to an early crystal structure determinaion. The filled circle no. 13 is found from a recent refinement of the crystal structure determination [96]. Compounds corresponding to the given numbers: 1) 2,3-dichloro5,6-dicyano-p-benzoquinone; 2) 2,3,4,4,5,6-hexachloro-2,5cyclohexadiene-1-one; 3) 2,3,4,4-tetrachloro-1-oxo-1,4-dihydronaphthaline $(\beta$-TKN); 4) 2,3,5,6-tetrachloro-p-benzoquinone (chloranil); 5) chloranil - perylene; 6) 2,5-dichloro3,6-dihydroxy-p-benzoquinone; 7) 2,2,3,4-tetrachloro-1-oxo1,2-dihydronaphthaline $(\alpha$-TKN); 8) 2,4,4,6-tetrachloro-2,5cyclohexadiene-1-one; 9) 2,4,4-trichloro-1,4-dihydronaphth[1,8-cd]isothiazole-1,1-dioxide (TCNS); 10) 2,5-dichloro-pbenzoquinone; 11) 2,6-dichloro-p-benzoquinone; 12) 2,4,4,6tetrachloro-3,5-dimethyl-2,5-cyclohexadiene-1-one; 13) 2,3dichloro-1,4-napthoquinone (phase I); 14) 2,3-dichloro1,4-naphthoquinone (phase II).

Several chlorocyclodienones have been studied and $v\left({ }^{35} \mathrm{Cl}\right)$ was correlated with $d(\mathrm{C}-\mathrm{Cl})$ [95]. A linear correlation results, shown in Fig. 6 , which includes some very recent results.

In Fig. 6 there are two points (both with no. 13) shown for 2,3-dichloro-1,4-naphthoquinone (phase I, $\left.\mathrm{C}_{i}^{1}-\mathrm{P} \overline{1}\right)$. The breakdown of the correlation $v\left({ }^{35} \mathrm{Cl}\right)$ $=f\left(d^{-3}(\mathrm{C}-\mathrm{Cl})\right)$ led us to a refinement of the crystal structure with good results [96]; the point no. 13 in
Fig. 6 nearer to the regression line results from the refinement of the crystal structure determination.

There are many correlation studies, halogen-NQR as a function of bond distances, on bonds $\mathrm{R}-\mathrm{X}$, where $\mathrm{X}$ is a halogen and $\mathrm{R}$ may contain carbon atoms, but not directly connected to the atom $\mathrm{X}$. Scaife and his colleagues related $d(\mathrm{R}-\mathrm{X})$ to a number of radicals $\mathrm{R}$ [97] such as $\mathrm{R}-\mathrm{Cu}^{\mathrm{II}}-\mathrm{Cl}$ [98] etc. $\mathrm{NQR}$ experiments on halogeno complexes of $\mathrm{Cu}^{\mathrm{II}}$ and $\mathrm{Zn}^{\mathrm{II}}$ are discussed in [99], bonds $\mathrm{R}-\mathrm{Hg}-\mathrm{Cl}$ are extensively treated in [100].

In compounds with halogen bound to group $\mathrm{V}$ atoms, Keat et al. [101] have studied the ${ }^{35} \mathrm{Cl}$ NQR as a function of $d(\mathrm{P}-\mathrm{Cl})$ in cyclophosphazenes. Ishihara [102] investigated complexes with $\mathrm{SbCl}_{3}$ and found a relation between $v\left({ }^{35} \mathrm{Cl}\right)$ and $d(\mathrm{Sb}-\mathrm{Cl})$. The ${ }^{35} \mathrm{Cl}$ $\mathrm{NQR}$ frequencies in five-membered ring chelate derivatives of antimony pentachloride were related to $d(\mathrm{Sb}-\mathrm{Cl})$ by Gerard-Dion and Lucken [103]; they found a linear relation, $v\left({ }^{35} \mathrm{Cl}\right)=a-b \cdot d(\mathrm{Sb}-\mathrm{Cl})$.

From literature data of $v\left({ }^{127} \mathrm{I}\right)$, (transition $m= \pm 1 / 2$ $\leftrightarrow m= \pm 3 / 2$ ) in salts $\mathrm{MI}_{3}$, a correlation of the distance $d$ (terminal $\mathbf{I}$-central $\mathbf{I}$ ) in the $\mathbf{I}_{3}$-ion and the NQR frequency was found by Yoshioka et al. [104].

The group of compounds most widely chosen by NQR spectroscopists for a variety of investigations, are the hexahalogeno compounds with the $\mathrm{K}_{2} \mathrm{PtCl}_{6}$ type crystal structure (or similar packing). Particularly $\mathrm{Sn}^{\mathrm{IV}}$ as the central atom is favoured because an octahedral coordination appears also in molecular complexes $\mathrm{SnX}_{4} \cdot 2 \mathrm{~L}$, where $\mathrm{L}$ is a neutral ligand. Additionally, the frequency range of ${ }^{35} \mathrm{Cl} \mathrm{NQR}$ is in a convenient experimental range. Feshin et al. [105] found a correlation between the bond distances $d(\mathrm{Ge}-\mathrm{Cl})$ and $v\left({ }^{35} \mathrm{Cl}\right)$ in compounds $\mathrm{Cl}_{3} \mathrm{GeR}$, and Huggett et al. [106] have observed that in compounds $\mathrm{M}_{2} \mathrm{SnCl}_{6}$ and $\mathrm{SnCl}_{4} \cdot 2 \mathrm{~L}$ the distance $d(\mathrm{Sn}-\mathrm{Cl})$ correlates well with $v\left({ }^{35} \mathrm{Cl}\right), v\left({ }^{35} \mathrm{Cl}\right)=a-b \cdot d(\mathrm{Sn}-\mathrm{Cl})$. In this correlation, the range of bond lengths was $231 \leqq d(\mathrm{Sn}-\mathrm{Cl}) / \mathrm{pm} \leqq 247$. We have studied recently a large variety of compounds with bonds $\mathrm{Sn}-\mathrm{Cl}$ [107]. The range of $d(\mathrm{Sn}-\mathrm{Cl})$ covered is $231 \leqq d(\mathrm{Sn}-\mathrm{Cl}) /$ $\mathrm{pm} \leqq 272$; hexachloro salts $\left[\mathrm{SnCl}_{6}\right]^{2-}$, pentachloro salts $\left(\mathrm{SnCl}_{5} \mathrm{R}\right)^{2-}$, compounds $\left[\mathrm{SnCl}_{4-x} \mathrm{R}_{x}\right] \cdot 2 \mathrm{~L}$, and molecules $\mathrm{SnCl}_{4-x} \mathrm{R}_{x}$ are included. The result is shown in Figs. 7 and 8 . The correlation is quite satisfying. On comparing Fig. 7 with Fig. 8, we note that the least squares regression lines differ only little for a plot $v\left({ }^{35} \mathrm{Cl}\right)=f\left(1 / d^{3}\right)$ and $v\left({ }^{35} \mathrm{Cl}\right)=\phi(d)$. This is understandable if one takes the short range of $d(\mathrm{Sn}-\mathrm{Cl})$ 


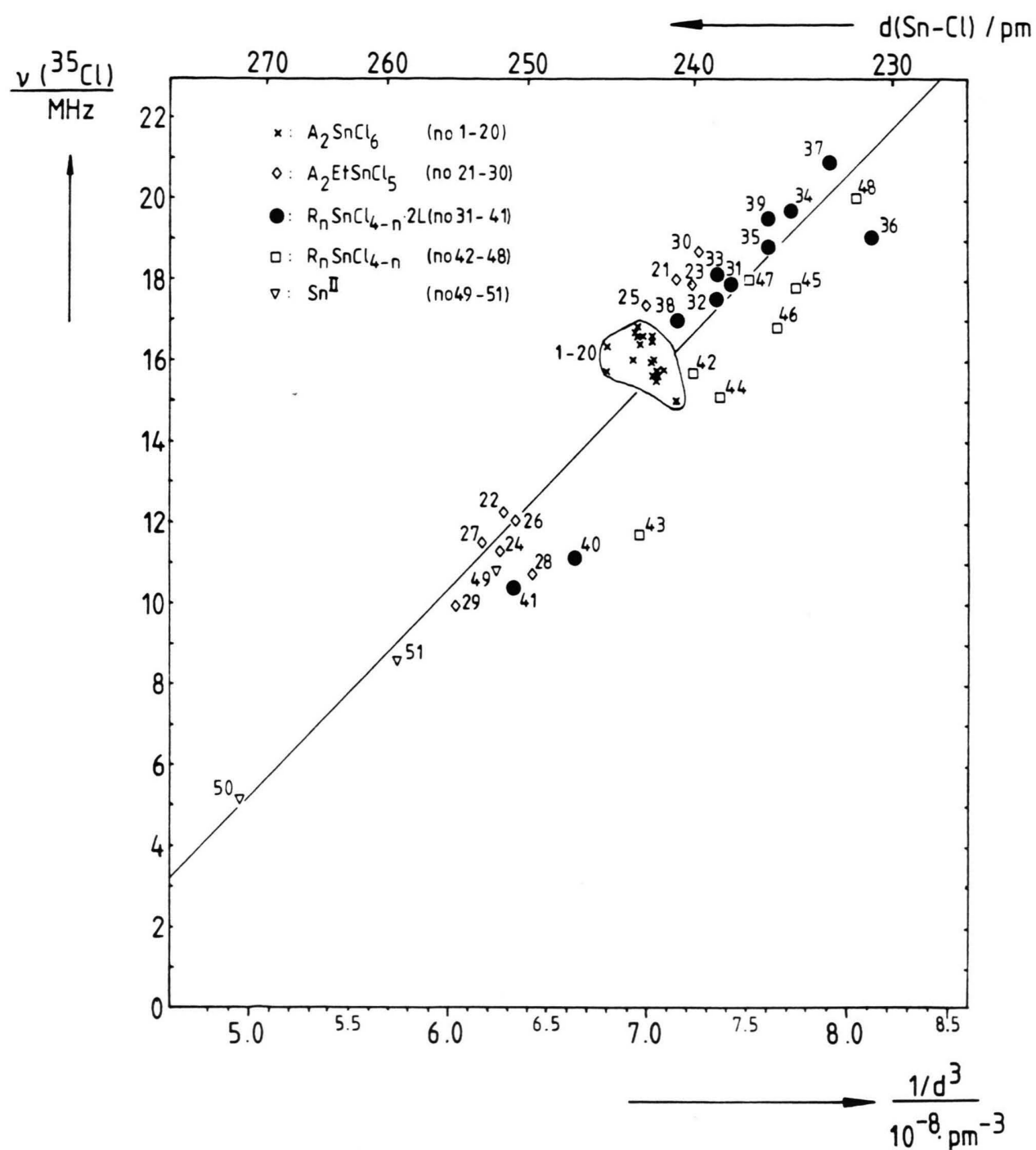

Fig. 7. ${ }^{35} \mathrm{Cl} \mathrm{NQR}$ frequencies of compounds with bonds $\mathrm{Sn}-\mathrm{Cl}$ vs. the bond distance $1 / d^{3}(\mathrm{Sn}-\mathrm{Cl})$. The symbols in the drawing mean: $\times$ : $\mathbf{A}_{2} \mathrm{SnCl}_{6}(\mathrm{No} .1-20), \mathrm{A}$ : 1) $\mathrm{K}$; 2) $\mathrm{NH}_{4}$; 3) Rb; 4) Cs; 5) $\left(\mathrm{CH}_{3}\right)_{4} \mathrm{~N}$; 6) $\mathrm{A}_{2}=\mathrm{Ni}_{(}\left(\mathrm{H}_{2} \mathrm{O}\right)_{6}$; 7) $\mathrm{CH}_{3} \mathrm{NH}_{3}$;

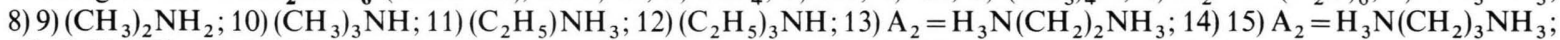
16) $\mathrm{C}_{5} \mathrm{H}_{5} \mathrm{NH}$; 17) 4-ClC $\mathrm{H}_{4} \mathrm{NH}$; 18) 19) $\mathrm{A}_{2}=\mathrm{C}_{4} \mathrm{H}_{12} \mathrm{~N}_{2} \cdot 3 \mathrm{H}_{2} \mathrm{O}$; 20) $\left(\mathrm{C}_{6} \mathrm{H}_{5}\right)_{2} \mathrm{CNH}_{2} . \diamond: \mathbf{A}_{2} \mathbf{E t S n C l}_{5}\left(\mathrm{No}_{2}\right.$ 21-30), A: 21) 22) $\left.\left(\mathrm{CH}_{3}\right)_{4} \mathrm{~N} ; 23\right)$ 24) $\left.\left.\left.\mathrm{C}_{5} \mathrm{H}_{5} \mathrm{NH} ; 25\right)-29\right) \mathrm{CH}_{3} \mathrm{NH}_{3} ; 30\right) 4-\mathrm{CH}_{3} \mathrm{C}_{5} \mathrm{H}_{4} \mathrm{NH}$. $\bullet: \mathbf{R}_{\boldsymbol{n}} \mathbf{S n C l}_{4-\boldsymbol{n}} \cdot \mathbf{2} \mathbf{L}$ (No. $31-39: n=0 ;$ No. 40, 41: $n=2$, $\left.\mathrm{R}=\mathrm{CH}_{3}\right)$; L: 31) HMPT; 32) DMSO; 33) $\left(\mathrm{C}_{6} \mathrm{H}_{5}\right)_{3} \mathrm{PO}$; 34) $\left(\mathrm{CH}_{3}\right) \mathrm{CN}$; 35)-37) $\mathrm{POCl}_{3}$; 38) 39) $\mathrm{SeOCl}_{2}$; 40) DMF; 41) DMSO. 口: $\mathbf{R}_{n} \mathrm{SnCl}_{4-n}$ (No. 42-48): 42) $n=2, \mathrm{R}=\mathrm{CH}_{3}$; 43) $n=3, \mathrm{R}=\mathrm{CH}_{3}$;44) $n=2, \mathrm{R}=\mathrm{C}_{2} \mathrm{H}_{5}$; 45) $n=2, \mathrm{R}=\mathrm{C}_{6} \mathrm{H}_{5}$; 46) $n=3$, $\left.\left.\left.\left.\left.\mathrm{R}=\mathrm{C}_{6} \mathrm{H}_{5} ; 47\right) n=2, \mathrm{R}=\mathrm{ClCH}_{2} ; 48\right) n=1, \mathrm{R}=3-\mathrm{ClC}_{3} \mathrm{H}_{6} . \nabla: \mathrm{Sn}^{\text {II }}(\mathrm{No} .49-51): 49\right) \mathrm{CsSnCl}_{3} ; 50\right) \mathrm{SnCl}_{2} ; 51\right) \mathrm{SnCl}_{2} \cdot 2 \mathrm{H}_{2} \mathrm{O}$.

available into account. Unfortunately, the plot $v\left({ }^{35} \mathrm{Cl}\right)=f\left(d^{-3}\right)$ is, therefore, not a proof of $(1)$.

The dependence $v\left({ }^{35} \mathrm{Cl}\right)=f\left(d^{-3}\right)$ for hexachlorotellurates is shown in Fig. 9 [108].

We have tried to understand on a quantitative basis such a simple relation as $v=a+b \cdot d^{-3}$. The EFG at the ${ }^{35} \mathrm{Cl}$ site in compounds of the $\mathrm{K}_{2} \mathrm{PtCl}_{6}$-type was calculated [109] on the basis of the X $\alpha$-method. The outcome of the calculation can be interpreted in the following way: The EFG at the Cl-site is the sum of the intraionic $\left[\mathrm{XCl}_{6}\right]^{2-}$ gradient and the lattice contribution. The main part is the intraionic one; the lattice part is of opposite sign. Increase of the lattice constant therefore increases the EFG and the frequency $v\left({ }^{35} \mathrm{Cl}\right)$. In case of dominant ionic bond within the complex ion, as it is found in $\mathrm{A}_{2} \mathrm{MX}_{6}, \mathrm{~A}=$ alkali metal 


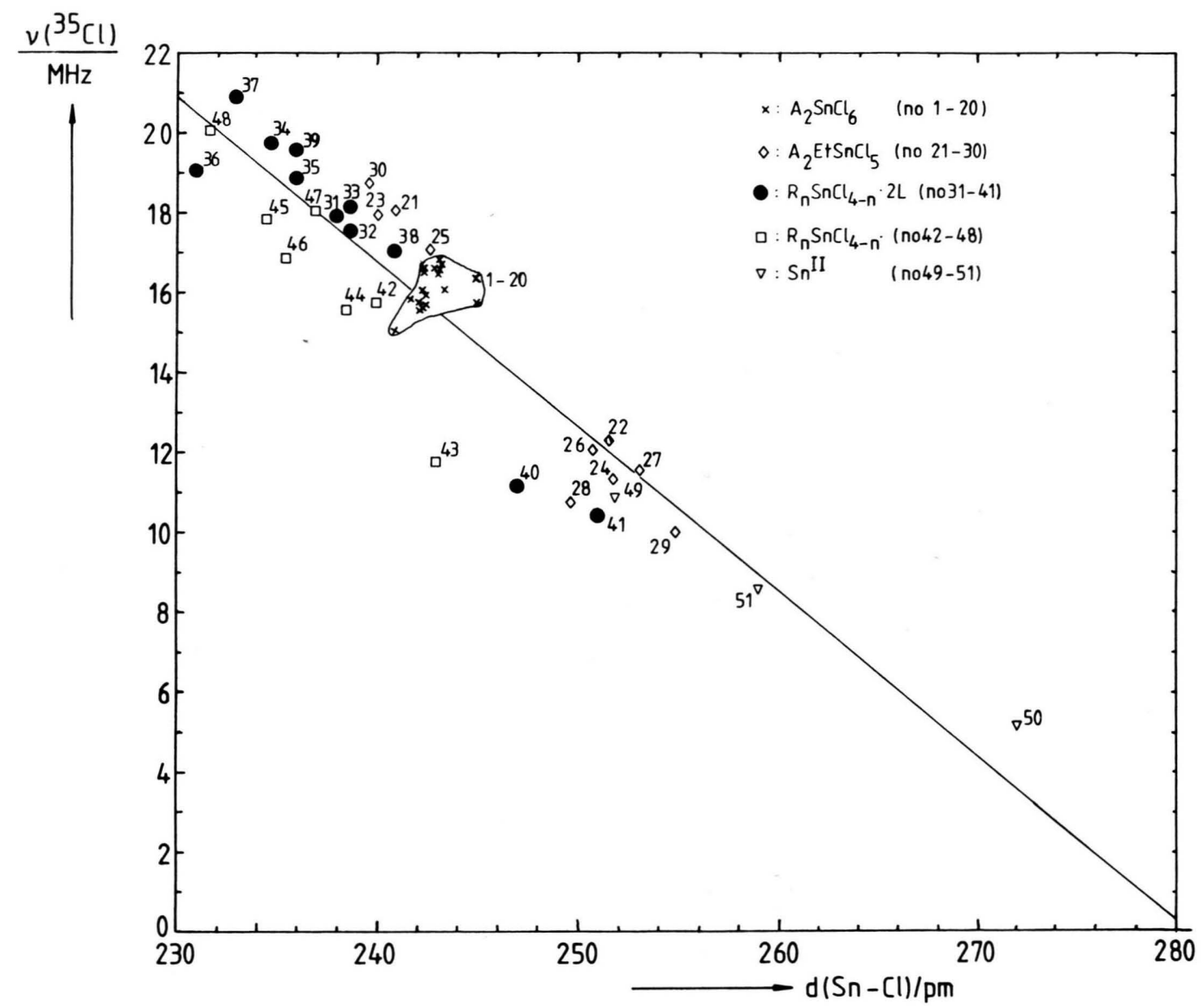

Fig. $8 .{ }^{35} \mathrm{Cl} \mathrm{NQR}$ frequencies vs. $d(\mathrm{Sn}-\mathrm{Cl})$. The symbols in the Figure are explained in the legend to Figure 7.

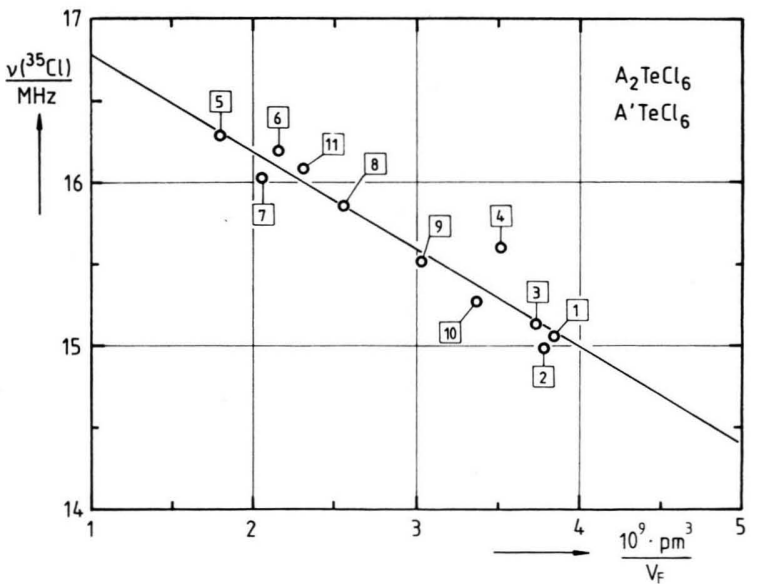

Fig. 9. ${ }^{35} \mathrm{Cl}$ NQR frequencies vs. the reciprocal volume of the unit cell per formula unit, $1 / V_{\mathrm{F}}$, for hexachlorotellurates. The numbers in the Figure symbolize the following cations: 1) $\mathrm{K}^{+}$; 2) $\mathrm{NH}_{4}^{+}$; 3) $\mathrm{Rb}^{+}$; 4) $\mathrm{Cs}^{+}$; 5) $\left(\mathrm{CH}_{3}\right)_{4} \mathrm{~N}^{+}$; 6) $\left(\mathrm{CH}_{3}\right)_{3} \mathrm{NH}^{+}$; 7) $\left(\mathrm{CH}_{3}\right)_{3} \mathrm{~S}^{+}$; 8$)\left(\mathrm{CH}_{3}\right)_{2} \mathrm{NH}_{2}^{+}$; 9) $\mathrm{CH}_{3} \mathrm{NH}_{3}^{+}$; 10) $\left(\mathrm{H}_{3} \mathrm{~N}\left(\mathrm{CH}_{2}\right)_{2} \mathrm{NH}_{3}\right)^{2+}$;11) $\mathrm{C}_{5} \mathrm{H}_{5} \mathrm{NH}^{+}$. ion, $\mathrm{M}=\mathrm{Cd}^{\mathrm{II}}, \mathrm{X}=\mathrm{Br}$, the total $\mathrm{EFG}$ at the halogen site decreases with increasing lattice constant [110].

Brill et al. [111] have correlated ${ }^{35} \mathrm{Cl}$ NQR frequencies and bond distances by scaling the results to the frequencies $v\left({ }^{35} \mathrm{Cl}\right)$ in compounds with $\left[\mathrm{SnCl}_{6}\right]^{2-}$ as anion. The result, including more recent data [108], is shown in Figure 10.

Information on $v(\mathrm{NQR})=f$ (bond length) can be found in case of group III a halides and halogeno complexes, too. Both, the central atom $\mathrm{M}^{\mathrm{III}}$ and the halogen ligand $\mathrm{X}$ give information via NQR. As examples we mention studies on the compounds $\mathrm{A}_{2} \mathrm{InX} \mathrm{X}_{5} \cdot \mathrm{H}_{2} \mathrm{O}, \mathrm{A}=\mathrm{K}, \mathrm{NH}_{4}, \mathrm{Rb}, \mathrm{Cs} ; \mathrm{X}=\mathrm{Cl}, \mathrm{Br}[112$, 113]. Replacing a smaller cation by a larger one, the halogen $\mathrm{NQR}$ frequencies $v\left({ }^{35} \mathrm{Cl}\right), v\left({ }^{81} \mathrm{Br}\right)$ increase and $e \Phi_{z z} Q h^{-1}\left({ }^{115} \mathrm{In}\right)$ decreases in accordance with the weighted contributions of the anion (intraionic) and the lattice contribution to the EFG. Yamada and Okuda [114] discussed the NQR results for the com- 


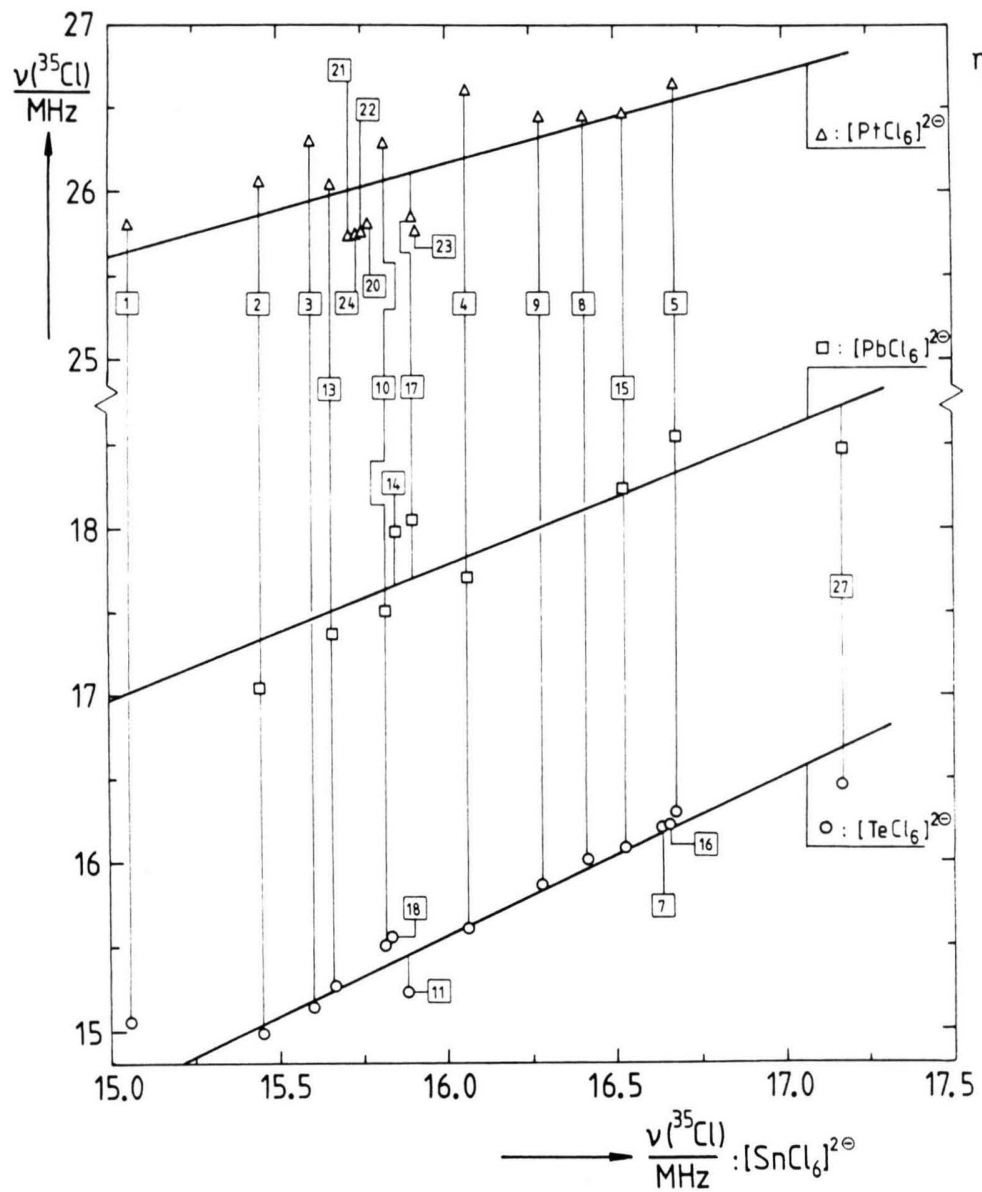

Fig. 10. Plot of the ${ }^{35} \mathrm{Cl} \mathrm{NQR}$ frequencies of the hexachlorometallates (IV) $\left[\mathrm{MCl}_{6}\right]^{2-}, \mathrm{M}=\mathrm{Te}, \mathrm{Pb}, \mathrm{Pt}$, versus the ${ }^{35} \mathrm{Cl} \mathrm{NQR}$ frequencies of the corresponding hexachlorostannate, $\left[\mathrm{SnCl}_{6}\right]^{2-}$. The numbering $(1-5)$ of the data points corresponds with the numbers given in the legend to Fig. 9. 6) $\left(\mathrm{C}_{2} \mathrm{H}_{5}\right)_{3}\left(\mathrm{CH}_{3}\right) \mathrm{N}^{+}$; 7) $\left(\mathrm{CH}_{3}\right)_{3} \mathrm{NH}^{+}$; 8) $\left(\mathrm{CH}_{3}\right)_{3} \mathrm{~S}^{+}$; 9) $\left(\mathrm{CH}_{3}\right)_{2} \mathrm{NH}_{2}^{+}$; 10) $\mathrm{CH}_{3} \mathrm{NH}_{3}^{+}$; 11) $\mathrm{C}_{2} \mathrm{H}_{5} \mathrm{NH}_{3}^{+}$; 12) $\left(\mathrm{C}_{2} \mathrm{H}_{5}\right)_{3} \mathrm{NH}^{+}$; 13) $\left(\mathrm{H}_{3} \mathrm{~N}\left(\mathrm{CH}_{2}\right)_{2} \mathrm{NH}_{3}\right)^{27}$; 14) $\left.\left.\left.\left(\mathrm{H}_{3} \mathrm{~N}\left(\mathrm{CH}_{2}\right)_{3} \mathrm{NH}_{3}\right)^{2+} ; 15\right)\left(\mathrm{C}_{5} \mathrm{H}_{5} \mathrm{NH}\right)^{+} ; 16\right) 4-\mathrm{ClC}_{5} \mathrm{H}_{4} \mathrm{NH}^{+} ; 17\right)$ $\left.\left.\left(\mathrm{C}_{3} \mathrm{H}_{12} \mathrm{~N}_{2}\right)^{2+} ; 18\right)-26\right) \mathrm{M}\left(\mathrm{H}_{2} \mathrm{O}\right)_{6}^{2+}, \mathrm{M}=\mathrm{Mg}, \mathrm{Ca}, \mathrm{Mn}, \mathrm{Ni}, \mathrm{Co}, \mathrm{Cd}, \mathrm{Zn}, \mathrm{Fe}$, $\mathrm{Cu} ; 2$ 2) $4-\mathrm{CH}_{3} \mathrm{C}_{5} \mathrm{H}_{4} \mathrm{NH}^{+}$; etc.

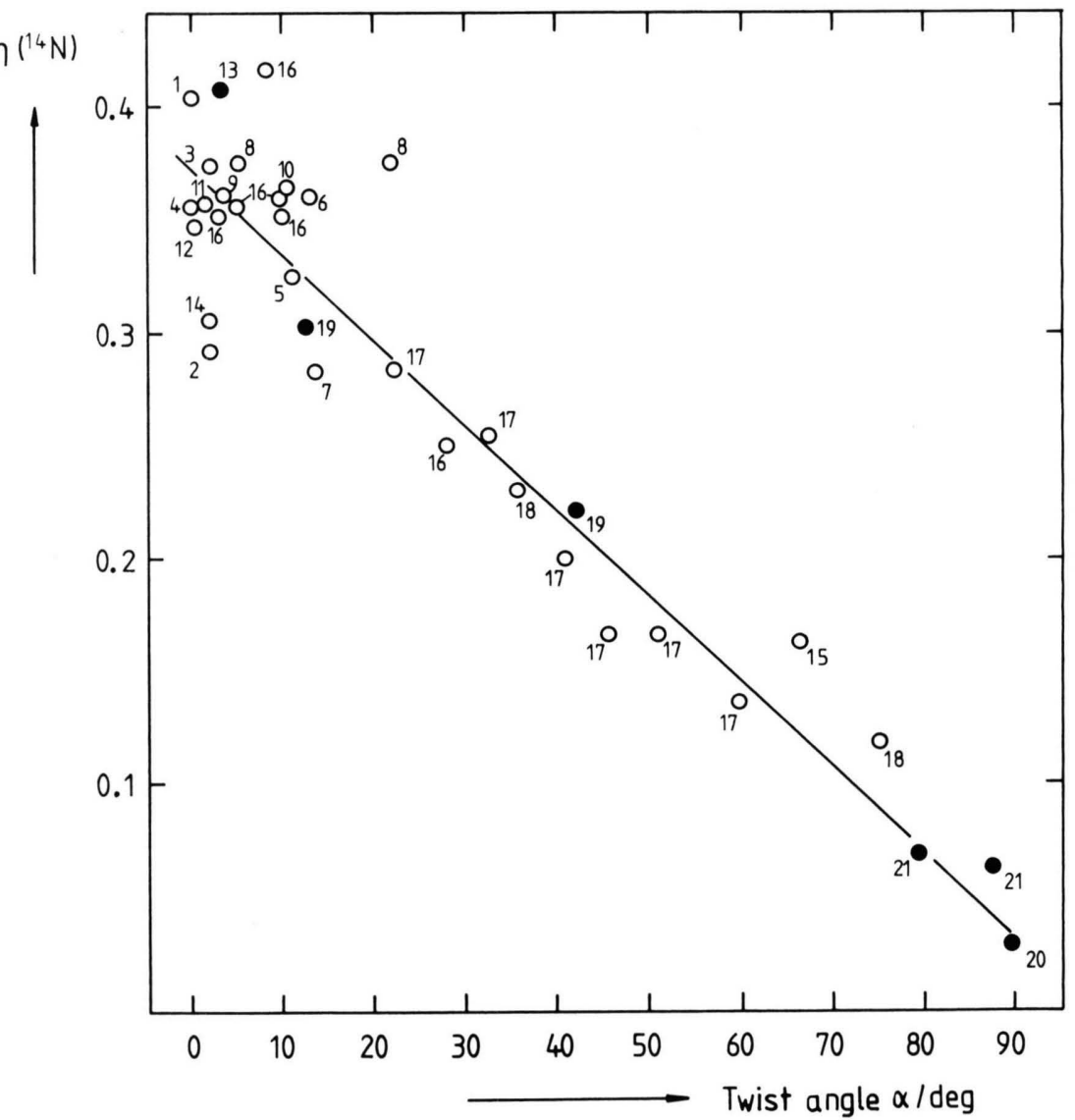

Fig. 11. Asymmetry parameter $\eta\left({ }^{14} \mathrm{~N}\right)$ vs. the twist angle $\alpha$ in substituted nitrobenzenes $\left(\alpha=\right.$ angle between the $\mathrm{C}_{6}$-ring plane and the $\mathrm{NO}_{2}$-plane). The numbering in the Figure corresponds to Table 2 . The points $13,19,20$, and 21 have been found from single crystal studies, QFS-NMR. The least squares analysis gives

$$
\eta\left({ }^{14} \mathrm{~N}\right)=0.374-0.004 \cdot(\alpha / \text { degree }) \text {. }
$$


pounds $\mathrm{A}\left[\mathrm{Al}_{2} \mathrm{Br}_{7}\right], \mathrm{A}=\mathrm{K}, \mathrm{NH}_{4},\left(\mathrm{CH}_{3}\right)_{4} \mathrm{~N},\left(\mathrm{C}_{2} \mathrm{H}_{5}\right)_{4} \mathrm{~N}$, and found a dependence of $v\left({ }^{81} \mathrm{Br}\right)$ on the cation radius.

\section{NQR and Bond Angles}

In chemical bond, bond distances are one prominent property characterizing the bond. Bond angles, however play also an important role in molecules, complex ions, etc. Bond lenghts and bond angles (or more general atomic distances, atomic coordination and angles in the coordination spheres) rule the structures of organic and inorganic complex compounds. From NQR experiments, there is a wealth of information available on coordination chemistry. A monograph, published in 1987, covers the subject thoroughly [115] and we shall not go into the connection of NQR and coordination chemistry here. There is, however, one point we wish to stress.

For substituted nitrobenzenes, a reasonable number of crystal structure determinations is available which show a pronounced degree of freedom in the twist angle $\alpha$ (angle between the $\mathrm{C}_{6}$ plane and the $\mathrm{NO}_{2}$ plane). Strong thermal vibrations are observed for such $\mathrm{NO}_{2}$ groups in X-ray diffraction, too. In the ideal case, like in nitrobenzene, the $\mathrm{NO}_{2}$ group is in the plane of the benzene ring, as one expects from a resonance system. Bulky ortho neighbors of the $\mathrm{NO}_{2}$ may force it to a twist. Marino and Connors [88] found a linear relation between the twist angle $\alpha$ and the asymmetry parameter $\eta\left({ }^{14} \mathrm{~N}\right)$ in nitrobenzene derivatives. In Fig. 11, we show a graph (including some recent data) of $\eta\left({ }^{14} \mathrm{~N}\right)=f(\alpha)$. The correlation is convincing, and in case of a few substituted polynitrobenzenes or in compounds with more than one formula unit in the asymmetric unit of the elementary cell the assignment $\eta\left({ }^{14} \mathrm{~N}\right) \leftrightarrow \mathrm{NO}_{2}$ group was proven by single crystal measurements (QFS-NMR). These compounds are marked in Fig. 11 by filled circles.

The QFS-NMR experiments have shown [77 a, 49, 50], that the main principal axis of the EFGT, $\Phi_{z z}$ at the ${ }^{14} \mathrm{~N}$ site of the $\mathrm{NO}_{2}$ group, is to an overwhelming extent parallel to the bond $\mathrm{C}-\mathrm{N}$ connecting ring and $\mathrm{NO}_{2}$ group. In the ideal case, twist angle $\alpha=0, \Phi_{x x}$ at the nitrogen site is parallel to the $\mathrm{C}_{6}$-ring plane and therefore parallel to the plane of the $\mathrm{NO}_{2}$ group. With increasing twist angle $\alpha, \Phi_{x x}$ stays neither parallel to the $\mathrm{C}_{6}$-plane nor parallel to the plane $\mathrm{NO}_{2}$ but lies somewhere in between. At $\alpha=90^{\circ}, \Phi_{x x}$ is again parallel to the ring plain and perpendicular to the $\mathrm{NO}_{2}$ plane,

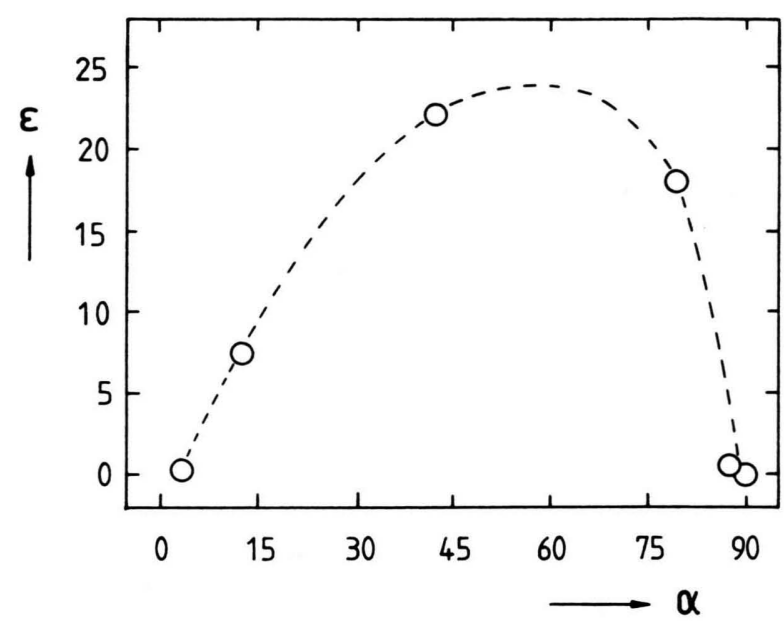

Fig. 12. Dependence of the angle $\varepsilon$ (angle $\Phi_{x x}, \mathrm{C}_{6}$ plane) on the twist angle $\alpha$. The data are from Table 2, No. 13, 19, 20, 21.

as observed in 2,3,5,6-tetrachloro-1,4-dinitrobenzene [50]. In a speculative way, we have drawn a curve relating the twist angle $\alpha$ and a twist angle $\varepsilon$, the latter one being defined as the angle between $\Phi_{x x}$ at the nitrogen site and the $\mathrm{C}_{6}$ plane. This is shown in Figure 12. The correlation $\varepsilon=f(\alpha)$ may be an interesting object for a theoretical (and experimental) study.

Compounds, must probably useful to ensure the dependence $\varepsilon=f(\alpha)$ shown in Fig. 12, would be 3,5dichloro-4-nitroaniline [91] and N,N-difluoroamino2,4,6-trinitrobenzene [91 a]. A twist angle of $64^{\circ}$ has been reported for the dichloro nitroaniline and three different angles $\alpha=28.20^{\circ}, 37.15^{\circ}$, and $62.22^{\circ}$ in the $\mathrm{N}, \mathrm{N}$-difluoroamino compound.

\section{Correlation of NQR and other Bond Dependent Physical Properties of Molecules in the Solid State}

The correlations of NQR results with properties of the chemical bond is part of the task of physical chemistry to find relations between physical properties and chemical bond parameters. In general, we may progress best by bring all the cross correlations available into the scenery.

A possibility of such a correlation parameter is the nuclear quadrupole splitting on tin-halogeno complexes found from Mössbauer experiments. Both, the EFG's at the Sn site and at the halogen site are available from a combined Mössbauer and NQR experiment. Investigations along this line are reported by Bryukhova et al. [116] and by Debye and Linzer [117]. 

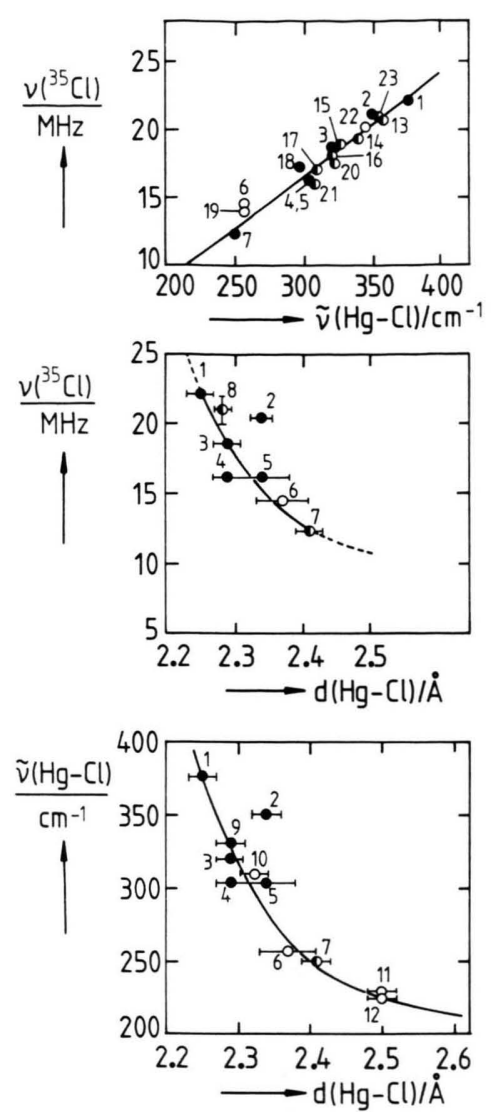

Fig. 13. Correlation of the NQR frequencies $\left({ }^{35} \mathrm{Cl}\right)$ of mercury chloride complexes, a) with the $\mathrm{Hg}-\mathrm{Cl}$-stretching frequencies, b) with the bond distances $d(\mathrm{Hg}-\mathrm{Cl})$; c) correlation of stretching frequencies $(\mathrm{Hg}-\mathrm{Cl})$ and bond distances $d(\mathrm{Hg}-\mathrm{Cl})$.

Unfortunately, Mössbauer spectroscopy is somewhat limited by the number of suitable nuclei. Combined experiments NQR $\left(I_{1}\right)-N Q R\left(I_{2}\right)$ are, however, possible for many systems. We have already mentioned the combination of In-NQR and halogen-NQR $[112,113]$ and of Al-NQR and halogen-NQR [114]. Other interesting "NQR-pairs" are As-Hal, Bi-Hal, Ga-Hal, B-Hal, etc. Hg-Hal would be an interesting pair in NQR on complexes; e.g. the bond distances $\mathrm{Hg}-\mathrm{Cl}$ cover a wide range [100] and ${ }^{201} \mathrm{Hg}(I=3 / 2)$ is accessible to the method as shown many years ago by Dehmelt et al. [118]. A further open problem in this context is the chemistry of gold-halogeno complexes $\left({ }^{197} \mathrm{Au}\right)$. The point of discussion here is, however, the cross correlation of NQR and information not gained from NMR-NQR.

A large body of information is available on the correlation of vibrational frequencies and chemical bond. A convincing relation between the stretching frequencies and ${ }^{35} \mathrm{Cl} \mathrm{NQR}$ frequencies was given by Scaife [100] for bonds $\mathrm{R}-\mathrm{Hg}-\mathrm{Cl}$ in $\mathrm{HgCl}_{2}$ and mercuri-halogeno complexes. Figure 13 shows the cross correlation found.

To us it appears that particularly in complexes with coordination $\mathrm{Hg}$-halogen one may find the wide range of distances $d$ (mercury-Hal) one observes for $d(\mathrm{Hg}-\mathrm{Cl})$, reaching from the short bonds in $\mathrm{HgCl}_{2}$ to the quite long ones in the complex salts, see Figure 13. This point is of interest because Fig. 13 a shows that the relation $v\left({ }^{35} \mathrm{Cl}\right)=f(d(\mathrm{Hg}-\mathrm{Cl}))$ is by no means linear. A linear relation exists, however, between $v\left({ }^{35} \mathrm{Cl}\right)$ and $\tilde{v}(\mathrm{Hg}-\mathrm{Cl})$.

The valence vibration frequency $\tilde{v}(\mathrm{C}-\mathrm{Cl})$ of chloro hydrocarbons correlates in a linear way with the NQR frequency $v\left({ }^{35} \mathrm{Cl}\right)$ as found by Gerdil [119]. For charge transfer complexes chloranil $\cdot \mathrm{X}$, the $\mathrm{C}=\mathrm{O}$ stretching frequency in the chloranil part was related to $v\left({ }^{35} \mathrm{Cl}\right)$ as was the stretching frequency $\tilde{v}(\mathrm{C}-\mathrm{Cl})$. The correlation $v\left({ }^{35} \mathrm{Cl}\right) \leftrightarrow \tilde{v}(\mathrm{C}=\mathrm{O})$ is, in contrast to that in $\mathrm{Hg}-\mathrm{Cl}$ complexes not linear [120], see also [121, 122].

A change in the charge distribution within a molecule by the effect of substitution or by the formation of molecular addition compounds should show up in the ionisation potential and in the polarographic half wave potential. The correlation NQR-ionisation potential was studied for $\pi-\pi$ molecular complexes by Maksyutin et al. [123]. Semin et al. [124] and Grechishkin and Kyuntsel [125] studied the dependence of the NQR frequency $v\left({ }^{35} \mathrm{Cl}\right)$ on the van der Waals radius of the donor molecule in such complexes. The half wave potential $U_{\frac{1}{2}}$ is, of course, connected with a charge transfer; the correlations found between the NQR frequencies $\left(v\left({ }^{35} \mathrm{Cl}\right), v\left({ }^{127} \mathrm{I}\right)\right)$ and $U_{\frac{1}{2}}$ is linear $[126,127]$.

The MO theory of NQR spectroscopy [10] as well as the Hammett $\sigma$ relations to NQR, discussed above, have to do with charge transfer. Hydrogen bonded complexes are proton charge transfer complexes and one expects a correlation between the $\Delta p K_{\mathrm{A}}$ of acidbase pairs and NQR frequencies. Typical examples are the compounds the medium strong acid trichloro acetic acid forms with bases [128]. A correlation $v\left({ }^{35} \mathrm{Cl}\right)=f\left(\Delta p K_{\mathrm{A}}\right)$ was pointed out by Maksyutin et al. [129]. Some more recent results are condensed in Fig. 14 [130].

Correlations of $v\left({ }^{35} \mathrm{Cl}\right)$ with $p K_{\mathrm{A}}$ data are found in the literature also for $\mathrm{Cl}_{2} \mathrm{HCCOOH} \cdot \mathrm{X}$ and for $\mathrm{Cl}_{5-x} \mathrm{C}_{6} \mathrm{H}_{x} \mathrm{OH} \cdot \mathrm{X}$. The dynamics of the $\mathrm{CCl}_{3}$ group 


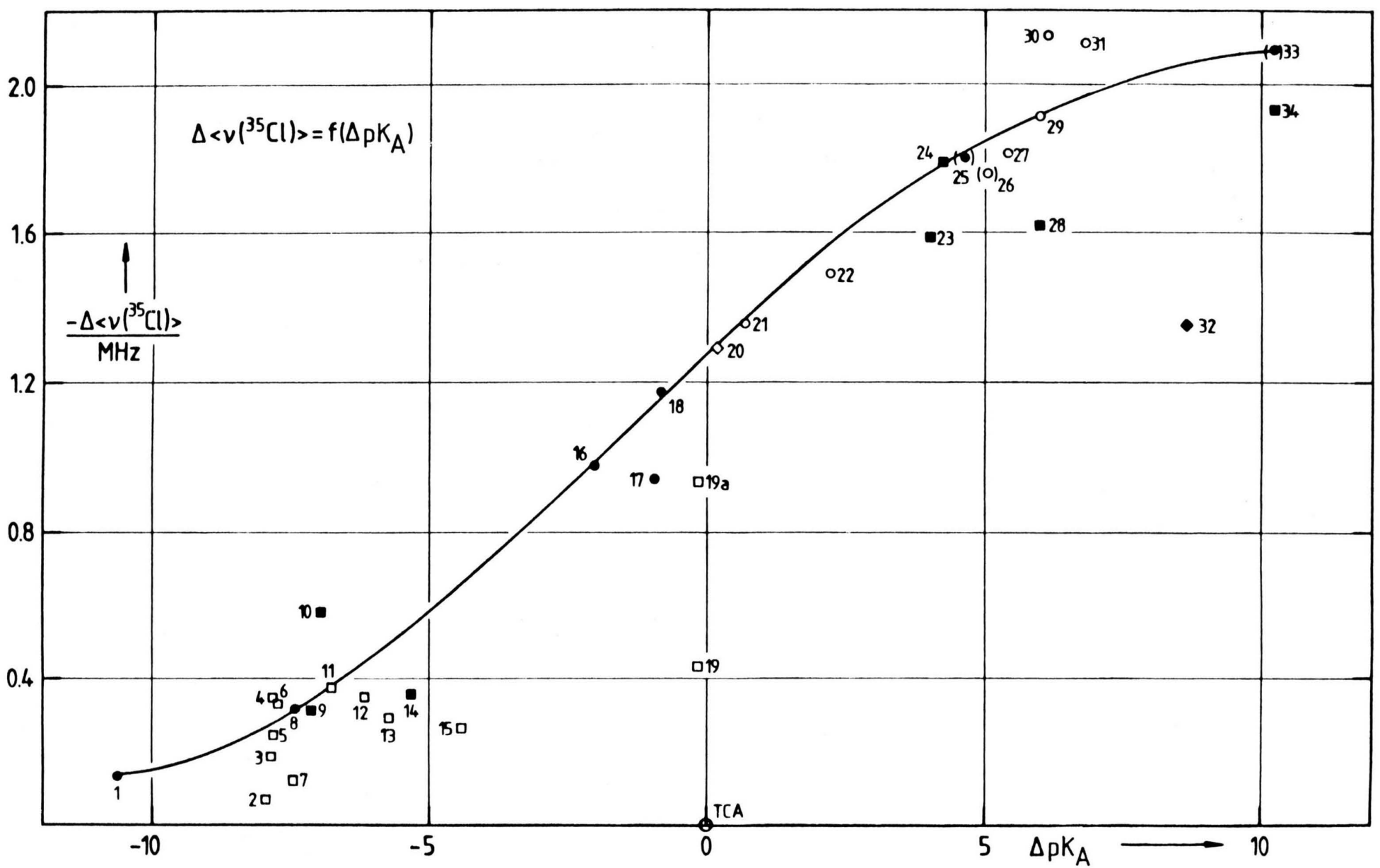

Fig. 14. Correlation of the ${ }^{35} \mathrm{Cl} \mathrm{NQR}$ frequencies of compounds $\mathrm{Cl}_{3} \mathrm{CCOOH} \cdot \mathrm{X}$ with the $p K_{\mathrm{A}}$ of the proton charge acceptor $\mathrm{X}$. The ${ }^{35} \mathrm{Cl} \mathrm{NQR}$ of the $\mathrm{CCl}$ group is described by the mean frequency shift $\Delta\left\langle v\left({ }^{35} \mathrm{Cl}\right)\right\rangle$ with respect to pure trichloro acetic acid, $\mathrm{Cl}_{3} \mathrm{CCOOH}$. For the numbers cf. [130]. 


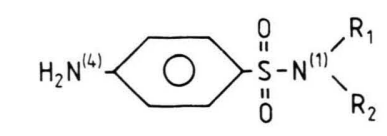

\begin{tabular}{|c|c|c|}
\hline $\mathrm{Nr}$. & $\mathrm{R}_{1}$ & $\mathrm{R}_{2}$ \\
\hline 1 & $\mathrm{H}$ & $\mathrm{H}$ \\
\hline 2 & $\mathrm{H}$ & $\mathrm{CH}_{3}$ \\
\hline 3 & $\mathrm{CH}_{3}$ & $\mathrm{CH}_{3}$ \\
\hline 4 & $\mathrm{H}$ & $\mathrm{COCH}_{3}$ \\
\hline 5 & $\mathrm{H}$ & $\mathrm{C}_{6} \mathrm{H}_{5}$ \\
\hline 6 & $\mathrm{H}$ & $\mathrm{CNCHCHCHCH}^{*}$ \\
\hline 7 & $\mathrm{H}$ & $\mathrm{CNCHCHS}^{* *}$ \\
\hline 8 & $\mathrm{H}$ & $\mathrm{SO}_{2} \mathrm{C}_{6} \mathrm{H}_{4} \mathrm{NH}_{2}$ \\
\hline 9 & $\mathrm{H}$ & $\mathrm{CNCHCHCHN}^{* * *}$ \\
\hline
\end{tabular}

* - pyridine

* * thiazole

**** - pyrimidine

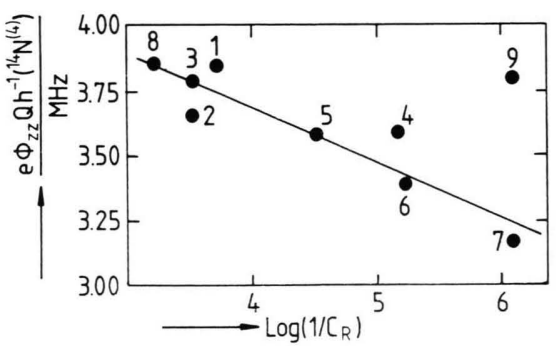

Fig. 15. Biological activity (in vitro) of sulfanilamides versus $e \Phi_{z z} Q h^{-1}\left({ }^{14} \mathrm{~N}^{(4)}\right) . C_{\mathrm{R}}$ is the biological activity of the compounds.

(bleaching out effect) in compounds $\mathrm{Cl}_{3} \mathrm{CCOOH} \cdot \mathrm{X}$ have been correlated with $v\left({ }^{35} \mathrm{Cl}\right)$, too [130]. We think that a more sensitive way to study correlations between hydrogen bond strength and electric field gradients would be ${ }^{2} \mathrm{H}$ QFS-NMR.

Lucken et al. [103 a] have correlated the $p K$-values of carboxylic acids with the ${ }^{35} \mathrm{Cl}-\mathrm{NQR}$ frequencies of carboxylates $\mathrm{RCO}_{2} \mathrm{SbCl}_{4}$.

[1] H. Dehmelt and H. Krüger, Naturwiss. 37, 111 (1950).

[2] H. Dehmelt and H. Krüger, Z. Phys. 129, 401 (1951).

[3] H. Dehmelt and H. Krüger, Z. Phys. 130, 385 (1951).

[4] R. Pound, Phys. Rev. 79, 685 (1950).

[5] T. P. Das and E. L. Hahn, Nuclear Quadrupole Resonance Spectroscopy, in: Solid State Physics (F. Seitz and D. Turnbull, eds.), Supplement 1 (1958).

[6] E. A. C. Lucken, Nuclear Quadrupole Coupling Constants, Academic Press, London, New York 1969.

[7] M. H. Cohen and F. Reif, Quadrupole Effects in NMR Studies of Solids, in: Solid State Physics (F. Seitz and D. Turnbull, eds.), 5, 322 (1957).

\section{NQR and Activity of Pharmaceuticals}

A most interesting connection between NQR frequencies (quadrupole coupling constants and EFGT's, respectively, and chemical bond was shown by Bray et al. [131-133] who investigated the correlation between the biological activity of nitrogen containing compounds and $e \Phi_{z z} Q h^{-1}\left({ }^{14} \mathrm{~N}\right)$. As an example, in Fig. $15 e \Phi_{z z} Q h^{-1}\left({ }^{14} \mathrm{~N}\right)$ is plotted versus the logarithm of the reciprocal bacteriostatic activity of sulfanilamides in vitro. It was possible to decide from the correlation the site of activity, which is $\mathrm{N}^{(4)}$.

Several groups of biologically active compounds, such as substituted anilines, nitrogen mustards and so on, have been the subject of the studies of Bray et al. (for a review of the work, see [131]). The correlations they found are convincing. The correlations of $e \Phi_{z z} Q h^{-1}\left({ }^{14} \mathrm{~N}\right)$ with the biological activity was also crosscorrelated by these authors with Hammett $\sigma$ [131]. There is hope that this rather new field of NQR will be a fruitful one in biochemistry.

\section{Conclusions}

The correlations of NQR parameters, the NQR frequencies, the nuclear quadrupole coupling constants $e \Phi_{z z} Q h^{-1}$, and the asymmetry parameters $\eta$ with direct (bond lengths, bond angles, coordinations) and indirect (ionicity, ionic character $i, s$-character, $\pi$-character, Hammett $\sigma$, kappa, etc.) bond parameters have given a lot of information and will do so in future. Cross correlations will help to establish quantitative relations. Single crystal NQR work will strengthen the quantitative character of them. We think that the correlations of NQR with biochemical properties of molecules will find increasing interest. Particularly ${ }^{14} \mathrm{~N}$ - and ${ }^{2} \mathrm{H}$ NQR may be of growing importance in this respect.

We are grateful to the Deutsche Forschungsgemeinschaft and to the Fonds der Chemischen Industrie for support.

[8] G. K. Semin, T. A. Babushkina, and G. G. Yakobson, Nuclear Quadrupole Resonance in Chemistry, J. Wiley \& Sons, New York 1975.

[9] H. Chihara and N. Nakamura, Nuclear Quadrupole Resonance Spectroscopy Data, in: Landolt-Börnstein (K. H. Hellwege and A. M. Hellwege, eds.), III, $20 \mathrm{a}, \mathrm{b}, \mathrm{c}(1988)$.

[10] C. H. Townes and B. P. Dailey, J. Chem. Phys. 17, 782 (1949).

[11] B. P. Dailey and C. H. Townes, J. Chem. Phys. 23, 118 (1955). 
[12] S. Kojima, K. Tsukada, and Y. Hinaga, J. Phys. Soc. Japan 10, 498 (1955).

[13] R. Bersohn, J. Chem. Phys. 22, 2078 (1954).

[14] D. Biedenkapp and Al. Weiss, J. Chem. Phys. 49, 3933 (1968).

[15] W. Pies, Dissertation, D17, Darmstadt 1978.

[16] S. Wigand, Dissertation, D17, Darmstadt 1989.

[17] C. Dean, Phys. Rev. 86, 607 (1952).

[18] H. Hartmann and H. Haas, Z. Naturforsch. 18a, 977 (1963).

[19] C. B. Richardson, Acta Crystallogr. 16, 1063 (1963).

[20] S. Sharma, N. Weiden, and Al. Weiss, Ber. Bunsenges. Phys. Chem. 90, 725 (1986).

[21] H. C. Meal, J. Chem. Phys. 24, 1011 (1956).

[22] C. Dean, M. Pollak, B. M. Craven, and G. A. Jeffrey, Acta Crystallogr. 11, 710 (1958).

[23] Y. Morino and M. Toyama, J. Phys. Soc. Japan 15, 288 (1960).

[24] S. Ogawa and K. Ohi, J. Phys. Soc. Japan 15, 1064 (1960).

[25] T. Sakurai, Acta Crystallogr. 15, 1164 (1962).

[26] T. Sakurai, Acta Crystallogr. 15, 443 (1962).

[27] T. Sakurai, M. Sundaralingam, and G. A. Jeffrey, Acta Crystallogr. 16, 354 (1963).

[28] V. Rehn, J. Chem. Phys. 38, 749 (1963).

[29] V. Nagarajan and C. R. K. Murty, Current Sci. 32, 254 (1963).

[30] P. Bucci, P. Cecchi, and A. Colligiani, J. Chem. Phys. 50, 530 (1969).

[31] B. Kantimati, Current Sci. 38, 335 (1969).

[32] A. Peneau and L. Guibé, C. R. Acad. Sci. Paris 26B, 1321 (1968).

[33] D. Sasikala and C. R. K. Murty, J. Phys. C 4(18), 3322 (1971).

[34] G. Chakrapani, C. V. Rama Sastry, and C. R. K. Murty, J. Phys. C 6, 1444 (1973).

[35] H. Negita, K. Shibata, and T. Kubo, Bull. Chem. Soc. Japan 48, 678 (1975).

[36] P. Venkatacharyulu and D. Premaswarup, J. Magn. Reson. 17, 117 (1975).

[37] J. L. Narajan, P. Venkatacharyulu, and D. Premaswarup, Ind. J. Pure and Appl. Phys. 13, 635 (1975).

[38] J. L. Narajan, C. Subrahmanyasastry, P. Venkatacharyulu, and D. Premaswarup, Ind. J. Pure and Appl. Phys. 13, 849 (1975).

[39] D. V. Ramanamurty, P. Venkatacharyulu, and D. Premaswarup, Ind. J. Pure and Appl. Phys. 13, 859 (1975).

[40] P. Venkatacharyulu and D. Premaswarup, Ind. J. Pure and Appl. Phys. 14, 914 (1976).

[41] D. V. Ramamurti, P. Venkatacharyulu, and D. Premaswarup, Ind. J. Pure and Appl. Phys. 17, 234 (1979).

[42] K. K. Vijaya Kumar, D. V. Ramanamurty,P. Venkatacharyulu, and D. Premaswarup, Proc. Ind. Acad. Sci. (Chem. Sci.) 89, 355 (1980).

[43] D. V. Ramanamurti, D. Srihari, P. Venkatacharyulu, and D. Premaswarup, Org. Magn. Res. 16(2), 123 (1979).

[44] N. Weiden, H. Paulus, and Al. Weiss, J. Mol. Struct. 111, 301 (1983).

[45] P. Venkatacharyulu, V. L. N. Prasad Nallagonda, K. K. Vijaya Kumar, and D. Premaswarup, Acta Phys. Pol. A 65(3), 259 (1984).

[46] V. Nagarajan, H. Paulus, N. Weiden, and Al. Weiss, J. Chem. Soc. Faraday Trans. 2, 82, 1499 (1986).

[47] S. Sharma, H. Paulus, N. Weiden, and Al. Weiss, Z. Kristallogr. 171, 101 (1985).

[48] S. Sharma, H. Paulus, N. Weiden, and Al. Weiss, Z. Naturforsch. 41 a, 134 (1986).
[49] S. Sharma, N. Weiden, and Al. Weiss, J. Chem. Phys. 90, 483 (1989).

[50] S. Wigand, N. Weiden, and Al. Weiss, Ber. Bunsenges. Phys. Chem. 93, 913 (1989).

[51] W. Gordy, W. Smith, and R. Trambarulo, Microwave Spectroscopy, J. Wiley \& Sons, New York 1953.

[52] M. A. Whitehead and H. H. Jaffé, Trans. Faraday Soc. 57, 1854 (1961).

[53] M. A. Whitehead and H. H. Jaffé, J. Chem. Phys. 34, 2204 (1961).

[54] M. A. Whitehead and H. H. Jaffé, Theor. Chim. Acta 1, 209 (1963).

[55] I. Miyagawa, J. Chem. Soc. Japan Pure Chem. Sect. 75, 1061 (1954).

[56] H. Hamano, Bull. Chem. Soc. Japan 31, 832 (1958).

[57] H. Hamono, Bull. Chem. Soc. Japan 37, L 583 (1964).

[58] H. C. Meal, J. Amer. Chem. Soc. 74, 6121 (1952).

[59] P. J. Bray, J. Chem. Phys. 22, 1787 (1954).

[60] P. J. Bray, J. Chem. Phys. 22, 2023 (1954).

[61] P. J. Bray and R. G. Barnes, J. Chem. Phys. 27, 551 (1957).

[62] H. O. Hooper and P. J. Bray, J. Chem. Phys. 33, 334 (1960).

[63] G. W. Ludwig, J. Chem. Phys. 25, 159 (1956)

[64] P. A. Casabella, P. J. Bray, S. L. Segel, and R. G. Barnes, J. Chem. Phys. 25, 1280 (1956).

[65] P. J. Bray, S. Moskowitz, H. Hooper, R. G. Barnes, and S. Segel, J. Chem. Phys. 28, 99 (1958).

[66] H. Hooper and P. J. Bray, J. Chem. Phys. 30, 957 (1959).

[67] M. Dewar and E. A. C. Lucken, J. Chem. Soc. 1958, 2653.

[68] E. N. Tsvetkov, G. K. Semin, D. I. Lobanov, and M. I. Kabachnik, Dokl. Akad. Nauk SSSR 161, 1102 (1965).

[69] I. P. Biryukov and M. G. Voronkov, Izv. Akad. Nauk Latv. SSR, Chem. Ser. 10, 39 (1969).

[70] I. P. Biryukov and M. G. Voronkov, Coll. Czech. Chem. Comm. Engl. Ed. 32, 830 (1967).

[71] C. P. Cheng and T. L. Brown, J. Magn. Reson. 28, 391 (1977).

[72] J. Trotter, Acta Crystallogr. 12, 884 (1959).

[73] K. N. Trueblood, E. Goldish, and J. Donohue, Acta Crystallogr. 14, 1009 (1961).

[74] A. C. Skapski and J. L. Stevenson, J. Chem. Soc. Perkin Trans. 2, 8, 1197 (1973).

[75] J. Trotter, Can. J. Chem. 39, 1638 (1961).

[76] J. Trotter and C. S. Williston, Acta Crystallogr. 21, 285 (1966).

[77] S. N. Subbarao and P. J. Bray, J. Chem. Phys. 67, 3947 (1977).

[77 a] Y. Hiyama and T. L. Brown, J. Chem. Phys. 75, 114 (1981).

[78] M. Colapietro and A. Domenicano, Acta Crystallogr. B 33, 2240 (1977).

[79] N. N. Dhaneshwar, S. S. Tavale, and L. M. Pant, Acta Crystallogr. B 30, 583 (1974).

[80] J. K. S. Kim, E. R. Boyko, and G. B. Carpenter, Acta Crystallogr. B 29, 1141 (1973).

[81] T. Higashi and K. Osaki, Acta Crystallogr. B 33, 2337 (1977).

[82] P. Coppens and G. M. J. Schmidt, Acta Crystallogr. 18, $62(1965)$

[83] F. Pandarese, L. Ungaretti, and A. Coda, Acta Crystallogr. B 31, 2671 (1975).

[84] J. V. Barve and L. M. Pant, Acta Crystallogr. B 27, 1158 (1971).

[85] F. Iwasaki and Y. Kawano, Acta Crystallogr. B 34, 1286 (1987). 
[86] Y. Hiyama and T. L. Brown, J. Phys. Chem. 85, 1698 (1981).

[87] J. Trotter, Acta Crystallogr. 12, 605 (1959).

[88] R. A. Marino and R. F. Connors, J. Mol. Struct. 111, 323 (1983).

[89] C. S. Choi and J. E. Abel, Acta Crystallogr. B 28, 193 (1972).

[90] W. R. Carper, L. P. Davies, and M. W. Extine, J. Phys. Chem. 86, 459 (1982).

[91] G. S. Ždanov and G. A. Golder, Zh. Fiz. Khim. SSSR 29, 1248 (1955).

[91 a] P. Batail, D. Grandjean, F. Dudragne, and C. Michaud, Acta Crystallogr. B 31, 1367 (1975).

[92] S. Wigand, L. Walz, N. Weiden, and Al. Weiss, Ber. Bunsenges. Phys. Chem. 91, 1189 (1987).

[93] M. Hashimoto, H. Paulus, and Al. Weiss, Ber. Bunsenges. Phys. Chem. 84, 883 (1980).

[94] M. Hashimoto, V. Nagarajan, N. Weiden, and Al. Weiss, J. Chem. Phys. 78, 618 (1983).

[95] S. Brummer, H. Paulus, and Al. Weiss, Z. Naturforsch. 43 a, 873 (1988)

[96] S. Brummer, U. Sohling, and Al. Weiss, Z. Naturforsch. 45a, 259 (1990).

[97] D. E. Scaife, Aust. J. Chem. 23, 2205 (1970).

[98] D. E. Scaife, Aust. J. Chem. 24, 1993 (1971).

[99] W. J. Asker, D. E. Scaife, and J. A. Watts, Aust. J. Chem. 25, 2301 (1972).

[100] D. E. Scaife, Aust. J. Chem. 24, 1753 (1971).

[101] R. Keat, A. L. Porte, D. A. Tong, and R. A. Shaw, J. Chem. Soc. Dalton Trans. II, 1648 (1972).

[102] H. Ishihara, J. Sci. Hiroshima Univ. Sect. A 45, 319 (1981).

[103] C. Gerard-Dion and E. A. C. Lucken, J. Chem. Soc. Perkin Trans. II, 545 (1985).

C. Gerard-Dion, J. Rupp-Bensadon, and E. A. C. Lucken, Z. Naturforsch. 41 a, 179 (1986).

[104] Y. Yoshioka, N. Nakamura, and H. Chihara, J. Mol. Struct. 111, 151 (1983).

[105] V. P. Feshin, P. H. Nikitin, M. G. Voronkov, T. K. Gar, N. A. Viktorov, A. N. Gurkova, A. I. Gusev, and V. I. Shiryaev, Zh. Obsh. Khim. 54, 646 (1984).

[106] P. G. Huggett, R. J. Lynch, T. C. Waddington, and K. Wade, J. Chem. Soc. Dalton Trans. 1980, 1164.

[107] P. Storck and Al. Weiss, Ber. Bunsenges. Phys. Chem. 94, 179 (1990).

[108] D. Borchers and Al. Weiss, Ber. Bunsenges. Phys. Chem. 93, 559 (1989).

[109] D. Borchers, P. C. Schmidt, and Al Weiss, Z. Naturforsch. 43 a, 643 (1988).
[110] V. G. Krishnan and Al. Weiss, J. Mol. Struct. 176, 323 (1988).

[111] T. B. Brill, R. C. Gaerhart, and W. A. Welsh, J. Magn. Reson. 13, 27 (1974).

[112] K. Yamada and Al. Weiss, Ber. Bunsenges. Phys. Chem. 87, 932 (1983).

[113] K. Yamada, N. Weiden, and Al. Weiss, J. Mol. Struct. 111, 217 (1983).

[114] K. Yamada and T. Okuda, J. Phys. Chem. 89, 4269 (1985).

[115] J. A. Buslaev, L. Kolditz, and E. A. Kravčenko, Nuclear Quadrupole Resonance in Chemistry, VEB Deutscher Verlag der Wissenschaften, Berlin 1987; idem, Coord. Chem. Rev. 82, 3 (1987).

[116] E. V. Bryukhova, G. K. Semin, V. L. Goldanski, and V. V. Chrapov, Chem. Comm. 1968, 491.

[117] N. W. G. Debye and M. Linzer, J. Chem. Phys. 61, 4770 (1974).

[118] H. G. Dehmelt, H. G. Robinson, and W. Gordy, Phys. Rev. 93, 480 (1954).

[119] R. Gerdil, Nature London 212, 922 (1966).

[120] H. Chihara and N. Nakamura, Bull. Chem. Soc. Japan 44, 2676 (1971).

[121] Al. Weiss, Topics in Curr. Chem. 30, 3 (1972).

[122] Al. Weiss, Adv. in NQR (J. A. S. Smith, ed.) 1, 1 (1974).

[123] Yu. K. Maksyutin, T. A. Babushkina, E. N. Gur'yanova, and G. K. Semin, Theor. Chim. Acta 14, 48 (1969).

[124] G. K. Semin, V. I. Robas, V. D. H. Shteingarts, and G. G. Yakobson, Zh. Strukt. Khim. 6, 160 (1965).

[125] V. S. Grechishkin and I. A. Kyuntsel, Zh. Strukt. Khim. 7, 119 (1965).

[126] G. K. Semin and A. A. Fainzilberg, Z. Stukt. Khim. 6, 213 (1965).

[127] R. A. Caldwell and S. Hacobian, Aust. J. Chem. 21, 1 (1968).

[128] D. Biedenkapp and Al. Weiss, Ber. Bunsenges. Phys. Chem. 70, 788 (1966).

[129] Yu. K. Maksyutin, E. N. Gur'yanova, and G. K. Semin, Usp. Khim. 39(4), 727 (1970).

[130] W. Fichtner, A. Markworth, N. Weiden, and Al. Weiss, Z. Naturforsch. 41 a, 215 (1986).

[131] P. J. Bray and S. G. Greenbaum, J. Mol. Struct. 83, 35 (1982).

[132] S. N. Subbarao and P. J. Bray, J. Med. Chem. 22, 111 (1979).

[133] N. S. Kim and P. J. Bray, Org. Magn. Res. 15, 370 (1981). 